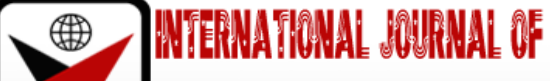

ISSN 2278 - 0211 (Online)

\section{Succession Under Esan Customary Law in Nigeria: Grounds for Disinheriting an Heir from Inheriting His Deceased Father's Estate under Esan Customary Law}

\author{
Paul Okhaide Itua \\ Senior Lecturer, Department of Commercial and Industrial Law, Ambrose Alli University, Nigeria
}

\begin{abstract}
:
In Nigeria, there are three main ethnic / tribal groups; these are Hausa - Fulani, Igbo and Yoruba. Apart from these major ethnic groups, there are about 371 (three hundred and seventy-one) other ethnic groups with diverse languages and phonological structures, which are some time noticeable even within the same socio cultural setting. Majority of these ethnic groups share a lot of historical and deep cultural relationship between them as evidence mostly in the application of customary law that regulate their private life on one hand and the relationship that exist between them on the other hand. Apart from these rules of customary law, the common law and statutory law equally plays a major role in the regulation of these relationships. Some time these rules of customary law are subjected to certain test as prescribed by the common law and the statute in other to determine their validity and applicability. These regulatory mechanisms, also apply to the people that constitute Esan ethnic group. They presently occupy Edo Central Senatorial District consisting of five local government areas in Edo State of Nigeria. Historically they share cultural relationship with the Edos in the area of customary law, however with some noticeable differences in its application in certain areas. One of such area is succession. The Edos are one of the largest ethnic groups in Edo state and they occupy Edo South Senatorial District consisting of seven local government areas. This article critically examines the rule of primogeniture which regulation succession to the estate of a deceased person within these two ethnic groups, and discusses in particular grounds under which a hair can be disinherited under Esan customary law.
\end{abstract}

Keywords: Succession under Esan customary law, the rule of primogeniture, heir, disinheritance

\section{Introduction}

Nigeria is pluralistic in terms of ethnicity, religion and law. ${ }^{1}$ The concept of legal pluralism has emerged in the social-legal discuss in Nigeria in the last few decades particularly in the area of theoretical perspective ${ }^{2}$. Thus, legal pluralism is evidently recognised in the area of law because of the complex interplay between common law, Statutes and Customary law. The interaction of these systems on common subject has resulted in a very complex system of internal conflict of laws, which causes controversy and disagreement. ${ }^{3}$ Legal pluralism in Nigeria takes three forms. Legal pluralism arising from the multifarious legal traditions or legal cultures; Nigeria laws are derived from three distinct laws or legal system, i.e. customary law which includes Islamic law ${ }^{4}$, the received English Common law and Local Statutes. The second form of pluralism arises from the fact that Federal and State government share legislative competence on the same subject matter. This has lead to a situation where differences exist with regard to one subject matter. While the third 'expression of pluralism is more connected with the country's political history. In a more simplistic form, legal pluralism is a situation where population observers more than one body of law. It is imperative to state that until 1954, there was no law on succession at the federal level. ${ }^{5}$ This lacuna was cured with the enactment of section 36 of the Marriage Act. 6 However, under the current Marriage Act, ${ }^{7}$ this provision dealing with succession has been removed. Apart from the provision of section 36 of the 1958 Marriage Act, the rule in Cole $v$ Cole ${ }^{8}$ was also used to determine the succession to the interstate estate of a deceased who contracted a Christian monogamous marriage outside the colony of Lagos but died

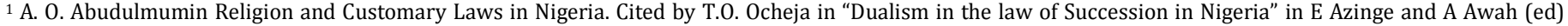
Legal Pluralism in Africa: A Compendium on Africa Customary Law (2012 Nigeria Institute of Advance Legal Studies Lagos) at 586.

2 I.Shahar, "Legal Pluralism and the Study of Shari'a Court" (2008 5 Islamic L \& 'y) at 112.

${ }^{3}$ I.E.Sagay Nigeria Law of Succession Principles, Cases, Statutes and Commentaries. (1 ${ }^{\text {st }}$ ed, 2006, Malthouse Press Limited). at 1.

${ }^{4}$ See Zaidan v. Zaidan [1974] 4UILR 283.

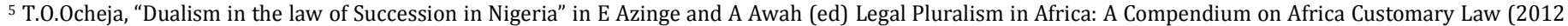

Nigeria Institute of Advance Legal Studies Lagos) at 586

${ }^{6}$ Cap. 115 Laws of the Federation of Nigeria 1958.

7 Cap. M6 Law of the Federation of Nigeria, 2004.
} 
while dormice in Lagos 9 . In 1954, succession became a regional matter by its inclusion in the concurrent legislative list of the Constitution Order-in-Council, 1954. However, in 1959, the then Western Region Administration of Estate Law of 1959 became effective throughout the region. Consequently, section 36 of the 1958 Marriage Act was repealed within the territorial jurisdiction of the Western Region. Interesting, this new law co-existed with the provision of section 36 of the Marriage Act, which still has force of law in the rest of the country at that time. On the other hand, succession to the intestate estate of a person who married under customary law continues to be governed by the rule of customary law. ${ }^{10}$ Usually, it is the deceased person's customs that will be applied with regard to his personal property ${ }^{11}$. In Administrator General v. Tunwase \& Ors ${ }^{12}$ the court held that Ijebu Ode is not a Mohammedan Emirate, which is common in the North. Therefore, the applicable law for the devolution of the property of the deceased is not that based on faith, which will justify the application of Mohammedan law but rather the applicable law is the Yoruba Native law and custom. Thus, Dualism of the law of succession generally, if viewed from the individualistic point of view, would not affect a Muslim for the simple reason that Islam has provided for the entire life of a Muslim. ${ }^{13}$ Some academic writers, because of the above stated reasons have opined that dualism in relation to a Muslim does not exist. For them, they argue that dualism can only exist for a non-Muslim who is governed by statutory law/or customary law. ${ }^{14}$ They further postulate that when a nonMuslim dies interstate, there is bound to be confusion as to which laws he is subjected to i.e., is it statutory law or customary law, that is the proper law which should be applied in the administration of his estate after death?

With due respect, I humbly submit that I do not share the sentiments of these writers. It is not true to say that when a non-Muslim die; there is usually confusion as to the laws that govern the intestate estate of the deceased. Although there is no one solution for the entire possible scenario that might arise, however depending on the situations that present it self, the answers are some time straightforward. According to Prof. Itse Sagay 15 , "the factors, that determine which system is to be applied in every case, is the type of marriage contracted by the intestate person while alive. In the case of Muslims, the religion practiced by the deceased is also relevant". Commenting further, he stated the principles of law as follows:

Thus, if a person contracts a Christian (monogamous) marriage outside Nigeria, the common law of England governs the distribution of his estate. If he contracts a statutory (Act) marriage in Nigeria, then if he dies domiciled in Lagos or any of the states comprising the old Western Region, then the Administration of Estate Law ${ }^{16}$ will govern. If he contracts a statutory marriage, but dies domiciled in any of the states comprising the former Northern or Eastern Regions, which are yet to enact their own law on non-customary succession, then the common law will also govern the distribution of his estate. ${ }^{17}$ Finally if the intestate person was an indigenous Nigerian and he did not contract a Christian or Act marriage, or even if he did, and no issue or spouse of such a marriage survived him, his estate will be distributed in accordance with the relevant customary law. If the intestate were a Muslim, then Islamic law would govern. ${ }^{18}$ Also, where a person who is subject to customary law or Islamic law dies intestate, it is his personal law that will apply to the distribution of his immovable property and not the lex situs..$^{19}$

Query, from the above, if a Muslim man marries a Christian woman in accordance with the Marriage Act, in Benin City, Edo State one of the states created out of the former Western Region that has its own Administration of Estate law and the Muslim subsequently dies interstate, what law will govern the administration of his interstate estate? This scenario become very apt when it is considered against the backdrop of the postulation made by writers' like Talatu Ocheja. $^{20}$

Dualism in the law of succession in Nigeria present itself both under the received English law, local statutes and under customary law. This classification is often term as Testate and Interstate Succession. Testate succession consists of wills. However, in Nigeria, there is no uniformity of applicable laws relating to will. ${ }^{21}$ This state of affairs has created some legal problems for the system. At a glance, some Nigerian Laws on testate succession includes but not limited to the Wills Act of 1837 and the Wills Amendment Act of 1852. These statutes are generally regarded as Statutes of General Application, which were in force in England on the $1^{\text {st }}$ of January 1900. Also, there is the Wills (Soldier and Sailors) Act of 1918. Some state in the federation has taken steps to enact their various Wills law. For example, the former Western Region enacted it Wills law in 1959.22 This law incorporated the provisions of the Wills Act and the Wills (Soldier and Sailors) Act of 1918. The provisions of this law have been replicated in most of the states created out of the former

\footnotetext{
${ }_{9}^{9}$ I.E Sagay, Nigeria Law of Succession Principles, Cases, Statutes and Commentaries. (Ist ed 2006 Malthouse Press Limited) at74.

10 C. O Margaret Family law (2003 Spectrum law series) at 352.

11 V.C. Ikpeze, Gender Dynamics of Inheritance Rights in Nigeria. Need for Women Empowerment. (2009 Folmech Printing \& Publishing Co. Ltd) at 143.

12 [1946] 18 NLR.8

13 T.O.Ocheja, "Dualism in the law of Succession in Nigeria" in E Azinge (ed) Legal Pluralism in Africa: A Compendium on Africa Customary Law (2012 Nigeria Institute of Advance Legal Studies Lagos) at 587.

14 Ibid.

15 I.E.Sagay, Nigeria Law of Succession Principles, Cases, Statutes and Commentaries. (1st ed, 2006, Malthouse Press Limited). at 73.

${ }^{16}$ Cap. 1, 1959 Laws of Western Nigeria $\square 17$ See Administrator -General v. Egbuna and Others. 18 NLR 1

${ }^{17}$ See Administrator -General v. Egbuna and Others. 18 NLR 1

${ }^{18}$ I.E. Sagay, Nigerian Law of Succession Principles, Cases Statutes and Commentaries, (1 ${ }^{\text {st }}$ ed, 2006, Malthouse Press Limited) at 73

${ }^{19}$ See Zaidan v. Zaidan above and section 13 of the Bendel State High Court Law.

${ }^{20}$ T.O.Ocheja, "Dualism in the law of Succession in Nigeria" in Legal Pluralism in Africa: A Compendium on Africa Customary Law (2012 Nigeria Institute of Advance Legal Studies Lagos page) at 587.

21 P.O.Itua "Legitimacy, Legitimation and Succession in Nigeria: An appraisal of Section 42 of the Constitution of the Federal Republic of Nigeria 1999 (as amended) on the Rights of Inheritance" (2012) Vol 4(3) Journal of Law and Conflict Resolution pages 31-44 cited in E. Azinge and A. Awah (ed) Legal Pluralism in Africa: A Compendium on Africa Customary Law (2012, Nigeria Institute of Advance Legal Studies Lagos) at 589.

22 Cap 133 Laws of Western Region of Nigeria 1959.
}

INTERNATIONAL JOURNAL OF INNOVATIVE RESEARCH \& DEVELOPMENT

DOI No. : 10.24940/ijird/2018/v7/i8/ 131085-317209-1-SM 
Western Region. For example, in Edo State, the Wills Law is a by-product of this process. In Anambra State, the applicable law is the Succession Law Edict of 1987. This local law governs testate inheritance in the state.

On the other hand, interstate succession involves three systems of laws. These are Common law, Administration of Estate Law and Customary law. Under these systems of laws, depending on the given circumstances, there are rules that govern the class of persons that can inherit the estate of the deceased. This article shall examine the grounds for disinheriting an heir from inheriting his deceased father's estate under customary law, with particular reference to Esan customary law.

\subsection{Nature of Property under Customary Law}

There are various definitions of the word property. Property has been defined as the right to possess, use, and enjoy a determinate thing, the right of ownership and as any external thing over which the rights of possession, use and enjoyment are exercised. ${ }^{23} \mathrm{~A}$ narrower proposition is that property is concerned with the ownership of objects. ${ }^{24}$ Generally, the term property can also be defined as any tangible or intangible possession that is owned by someone. ${ }^{25}$ Property may be divided into two broad classification of moveable and immoveable property. Often, the classification can assume the tangible and intangible connotation. Irrespective of the descriptive term used, they basically refer to the same thing. Although it may appear elementary, examples of property include but not limited to the following, chattels, land and buildings. In some situation it includes intellectual property, or chieftaincy titles. In Islam, acquisition of property by the individual (male or female) is recognized. There is no limitation placed upon the property or wealth, which an individual may acquire or give away under Islamic law. ${ }^{26}$

It is noteworthy to state that the law draws a shape distinction when determining issues concerning the classification of movable and immoveable properties. Under customary law, when determining issues relating to succession to moveable properties, the appropriate customs is the personal law of the deceased. ${ }^{27}$ On the other hand, when determining the issue bothering on land, the applicable law is the law of the place where the land is situated or the lex situs as the case maybe. However, with regard to issues bothering on inheritance and succession of immoveable property under customary law, the position of the law was aptly stated thus "It is important to note that while it is true that with respect to land matters generally, the customary law of the place where the land is situated is applicable. However, with respect to inheritance, the appropriate customary law is the customary law of the deceased and not the lex situs." ${ }^{28}$ Thus among the various communities in Nigeria, property is very fundamental to inheritance and succession. The reason for this is not farfetched. Apart from the classification into moveable and immoveable property, it's also important to examine the classification of property into personal and family property.

There are various principles of customary law that govern procedure to succession to family or personal property.

\subsection{Types of Property under Customary Law}

There appears to be uniformity on the types of properties under customary law in Nigeria. Amongst the various indigenous communities in Nigeria, the beneficiaries of a deceased person are entitled to inherit certain types of properties left behind by the deceased. These properties include but not limited to the following: land, wives, buildings, farmland, palm trees, domestic animals, houses, cars, clothes, jewellery, money and other personal properties. Among these classes of properties, land is regarded as a property that is all encompassing and all embracing. Land can be put to various uses. For example, it could be used for building purposes and as well for farming / livestock production. In most of the communities, inheritance of land is restricted to the male children of the deceased. Although land is capable of being owned either through communal ownership, family ownership, individual ownership and finally ownership by the state. For the purposes of this discuss, we shall examine family and individual ownership of land. Under customary law, it is an acceptable principle of customary law that land is communally owned. ${ }^{29}$ In Onowhosa v Odiuzou ${ }^{30}$ the Supreme Court held that the two courts below were right in holding that the land in dispute is held in communal ownership of both the Appellant and Respondents. It is interesting to note that among Umuahia communities of Abia State in the South -East of Nigeria, a trade is also capable of being inherited. Where the deceased is an artisan (a blacksmith or a palm wine tapper) there are ways of sharing his apparatus after his death to his beneficiaries. In such instance, the beneficiary who would replace him in that profession is also named. ${ }^{31}$ In Iwo, a child that has not grown up is also considered a property to be inherited and taken care of by the husband of the child's mother. Among the people of Mbaise land is consider a first-class property. The inheritance of land is mostly by men. It is a common practise amongst the Mbaise people that a woman does not own land while in her parent's house.

Although the practise of woman inheritance might seem despicable, to some persons, the practise of inhering wives as property after the death of their husband is very common and prevalent in the communities of the South-South, South-East and South -West. Among the South-East geopolitical zone of Nigeria, the concept of widow inheritance is

\footnotetext{
${ }^{23}$ Black's Law Dictionary $9^{\text {th }}$ Edition for iPhone/iPad/iPod touch. (2009-2013).

${ }^{24}$ R. J. Smith, Property Law ( $5^{\text {th }}$ ed, 2006, Pearson Longman) at 3

${ }^{25}$ See Word Web 32 Dictionary thesaurus/ dictionary

${ }^{26}$ Y. Y. Bambale, Acquisition and Transfer of Property in Islamic Law (2007 Malthouse Press Limited) at 11.

27 E. Azinge. Restatement of Customary Law of Nigeria ( $1^{\text {st }}$ ed, 2013, Nigeria Institute of Advance Legal Studies Lagos) at 78.

28 P.O.Itua, "Succession under Benin Customary Law in Nigeria: Igiogbe Matters Arising" (2011) Vol.3 (7) Journal of Law and Conflict Resolution page 119 cited in E. Azinge. (ed) Restatement of Customary Law of Nigeria (1 $1^{\text {st }}$ ed, 2013, Nigeria Institute of Advance Legal Studies Lagos) at 78-79.

${ }^{29}$ V.C. Ikpeze, Gender Dynamics of Inheritance Rights in Nigeria Need for Women Empowerment. (2009 Folmech Printing \& Publishing Co. Ltd) at 176177.

${ }^{30}$ [1999] 2NWLR (PT 586) 482.

${ }^{31}$ E. Azinge, Restatement of Customary Law of Nigeria (1 $1^{\text {st }}$ ed, 2013, Nigeria Institute of Advance Legal Studies Lagos) at 84.
}

INTERNATIONAL JOURNAL OF INNOVATIVE RESEARCH \& DEVELOPMENT ～DOI No. : 10.24940/ijird/2018/v7/i8/ 131085-317209-1-SM 
recognised. A man family may activate it on the death of the man. Were the family decide to activate this customary law procedure, the widow is 'inherited' by the deceased man's eldest brother who in turn become her new husband and she therefore retains her rights by cohabiting with him. ${ }^{32}$ But a direct contrast of this practise is found among Uruan community in the present day Akwa Ibom State where a wife is not regarded as a property for inheritance after the death of her husband. This rule of customary law dealing with widow inheritance has received judicial approval from the apex court in Nigeria. In Oke \& Anor v Oke \& Anor ${ }^{33}$ the Supreme Court held that under Urhobo customary law of succession, the wife or wives of the deceased Urhobo man are regarded as part of his property to be inherited after his death. The Supreme Court also expressed the same view in Akinnubi v Akinnubi. ${ }^{34}$ However, some writers have criticised the apex court for its view in endorsing this customary law practise. Commenting on the ratio in Akinnubi v Akinnubi, Ogugua V.C. Ikpeze started as follows: "that decision with all due respect to the revered Supreme Court Justices call for urgent review when similar cases appear before the Apex Court. Such custom cannot be encouraged by the courts in the $21^{\text {st }}$ century. To maintain that such a custom is lawful and acquiesce to such custom is to say the least ridiculous, unrealistic and unconstitutional." 35 I share the sentiment expressed above by the learned writer. This kind of custom must be adjudged to be repugnant to natural justice equity and good conscience. It totally dehumanised the woman and make her look like a second-class citizen among her peers within and outside the shores of the country.

As we have observed above, land remains as one of the most important property that can be inherited by an heir after the death of this father under customary law in Nigeria. The important of land cannot be over emphasised irrespective of the community in question. Apart from what is obtainable among the Yoruba speaking people of the south west where the gender of the child is immaterial when it concerns issues relating to succession, however the position obtainable in the rest of the country is the direct opposite with that of the south-west. In other words, the inheritance of land by the male children is prevalent. In these communities particularly amongst the south-east and south-south geopolitical zone of the country, woman cannot inherit land. It is important at this point to mention that in Orlu community in Imo State, it is permissible for a woman to build her house own and plant economic tress but it is forbidden to own land. Also, in some communities, women are generally not in contention when land is about to be inherited. The argument in most of these communities is that a woman property is in her husband's house, and not in her father's house. However, there has been a shift in judicial reasoning on the issue of female inheritance with particular reference to land in the Eastern part of the country. In Mrs Lois Chituru Ukeje \& Anor v. Mrs Gladys Ada Ukeje ${ }^{36}$ the Supreme Court of Nigeria per RHODES-VIVOUR JSC held that "Igbo customary law which disentitled a female child from partaking, in the sharing of her deceased father's estate is in breach of section 42 (1) and (2) of the Constitution, a fundamental rights provision guarantees to every Nigeria, the said discriminatory customary law is void as it conflicts with section 42(1) and (2) of the Constitution". Thus, under the present legal dispensation, it will be discriminatory to denial any female child the right to share or inherit her late father's land. Any community that still rely and practice this exclusionist custom, stand the risk of the custom being held as repugnant to natural justice equity and good conscience and the court will not hesitate to strike out such custom.

\subsection{Nature of Property under Customary Law}

Under customary law in Nigeria, properties may be classified generally as immovable or movable properties. Movable properties in many instances includes some of the following; - farm produce, clothes, cars, motorcycles, bicycles livestock, jewellery and finally money. On the other hand, immovable properties include land, which in most situations includes farmland and other improvement on it. These improvements could be in the form of building, cash crops etc., etc. These aforesaid classifications, i.e., movable and immovable properties could be further divided into family / communal properties and personal properties in relation to succession and inheritance. Family property are those properties which devolve from father to children and grand children under native law and custom and which no individual child or member of the family can dispose of until they are partitioned. ${ }^{37}$ Apart from this method, other methods of creating family property include the death of the intestate (devolution), conveyance inter vivos, Will and gift or allotment. In Frank Coker v. George Coker \& Ors ${ }^{38}$ Edward Foster, deceased, directed in his Will, which he made in English form, the following bequest of his dwelling house, which was situated in Lagos. "I leave and bequeath my present dwelling house to the whole family or blood relative and their children's children through out and can not be sold for any debt or debts that may be contracted by any of them, but at present the house should be occupied by my grandson Nath and my son Edward subject to the approval of my executors or otherwise..." His executors proved his Will, and the said dwelling house was subsequently sold by an order of court. In an action by summons to determine those who are entitled to share in the proceeds of the sale. The court held that the intention of the testator was to make his dwelling house a family house, following the Yoruba custom and that consequently, those entitled to share in the proceeds of its sale were those of his descendant under the customs to reside in the premises at the time of the sale. Also, in Adeleke v Iyanda ${ }^{39}$ his Lordship Uwaifo JSC (as he then was) stated at page 16 Para F-G that it is the family head with the concurrence of the principal member of the family who is the proper person to sell family land or property. In most of the communities in Nigeria, family land constitutes; land,

\footnotetext{
32 Ibid at 85 .

33 [1974] AII NLR p.401, see also the case of Obusez v Obuseez [2001] 5 NWLR (Pt. 736) 377,

34 [1997] 4NWLR (Pt.486) 144.

35 V.C. Ikpeze Gender Dynamics of Inheritance Rights in Nigeria Need for Women Empowerment (2009 Folmech Printing \& Pub. Co .Ltd) at 95.

36 [2014] LPELR 724 (SC).

37 E. Azinge, Restatement of Customary Law of Nigeria ( $1^{\text {st }}$ ed, 2013, Nigeria Institute of Advance Legal Studies Lagos) at 87.

38 [1938] 14 N.L.R. 83

39 [2001] 13 NWLR (Pt.729) 1
}

INTERNATIONAL JOURNAL OF INNOVATIVE RESEARCH \& DEVELOPMENT

DOI No. : 10.24940/ijird/2018/v7/i8/ 131085-317209-1-SM 
building, farmland, economic trees, other improvement on the land and in most cases, live stock. On the other hand, things such as domestic animals, houses, cars cloth etc., and other items constitute personal property. In some communities in Nigeria, inheritance of family property such as land and buildings are limited to the sons, in some of these communities, where the deceased dies without a son; the deceased's brother, or other male member of the family inherits the land. It's my humble view that these customs have out lived their usefulness; they ought to be struck down by our courts. They are discriminating in nature and they offend the provisions of Section 42 (2) of the 1999 Constitution, as epitomise in the case of Mrs Lois Chituru Ukeje \& Anor v. Mrs Gladys Ada Ukeje 40

Further more in some of these communities where these customs are practiced, the eldest son get the largest portion followed by the second son in the order of seniority. However, in certain part of the country, particularly among the Yoruba speaking communities, the rules are totally different. Here, daughters and other female member of the deceased family may inherit family property such as land and building. Two conditions may give rise to the operation of this custom. In the first instant, the deceased might die without leaving a male child. In other words, female children survived him only. The second situation is where the deceased has both male and female children, with the female being the eldest child. This was the situation that confronted the colonial court in the case of Lewis v Bankole ${ }^{41}$ where the court held that the eldest surviving female child succeeds where there is no male child surviving the deceased intestate. In Folami $v$ Cole $e^{42}$ the Appellant, as well as the $1^{\text {st }}$ Respondent were all children of one Adisatu Aina who died intestate in Lagos in 1951 leaving a large area of land at Abule now known as llupeju. Adisatu Aina had no male issue and the $1^{\text {st }}$ Respondent Flora Cole, was the eldest of his five children, who became joint owner of the land at Ilupeju under Yoruba Customary Law. It was alleged that the $1^{\text {st }}$ Respondent through her Attorneys, Edward Marsha and Nathaniel Marsh sold a portion of the land to one Mohammed Aderonmu Bamgobose, the $2^{\text {nd }}$ Respondent in 1962, who in turn sold it to the $3^{\text {rd }}$ Respondent Lasisi O.A. Iiaka in 1965. The $3^{\text {rd }}$ Respondent went into the land and erected a building on the land. The Appellant brought an action at the High Court to challenge the sale of the family land by the $1^{\text {st }}$ Respondent and the subsequent sale to the $2^{\text {nd }}$ Respondent and also to the $3^{\text {rd }}$ Respondent. They contented that although $1^{\text {st }}$ Respondent is the eldest child of Adisatu Aina, she was not the family head. The Court of Appeal held that under the Yoruba Customary Law, the eldest surviving child of the founder of the family called the Dawodu is generally recognized as the Head of the family, and the question of an election or appointment by the members of the family does not arise. That upon the death of the Dawodu, the eldest surviving child of the founder whether male or female, succeeds to the headship of the family. They further held that there are no reasons for making exceptions to the rule above where all the children are female so where there is no son, it follows that the eldest female succeeds to the headship of the family. This custom that ensures that an eldest surviving female of the founder of the family succeeds to the headship of the family where there is no eldest son or Dawodu has been judicially recognize. It is noteworthy to mention that in some communities, land given to a wife reverts to a male child (or other male relative) at her death. Thus, only personal properties of the deceased can be alienated. Conversely, a single individual cannot alienate family or communal land. In Amuda Adebambo \& 2 Ors v Daodu Olowosago \& 30rs. ${ }^{43}$ The Appellants (Plaintiff in the lower court) brought a claim for declaration of title against the Respondents (Defendants in the court below). Some members of the Plaintiff's family had sold the land in dispute to the defendant without the consent or concurrence of the head of the family and principal members of the family. Two members of the family brought the action on behalf of the Plaintiff's family. The trial judge dismissed the Plaintiffs claim; inter alia on the ground that the land in dispute being family land, the Plaintiff has no sufficient interest to enable them bring such action on behalf of the family. On further appeal to the Court of Appeal, the Court of Appeal set aside the judgment of the lower court and held that a member of the family lack the authority to alienate or sell family land without the consent and concurrence of the head of the family and other principal members of the family. However, family / communal property can be partitioned in other to transfer rights to individual family members.

Thus, allottees of family or communal land have only the right to occupy and use the land, they cannot alienate without first seeking the consent of the family or community. Therefore, an allocation to a member of a portion of family property does not extinguish the interest of the family in the land. The ownership of the land continues to inure in the family in the form of reversionary interest. In Gbamgbose v Osobu ${ }^{44}$ the Supreme Court drew a distinction between an allotment and an inheritance as follows: "An allotment of family property under customary law means more than mere permission or license from the family to make use of family land without creating ownership of the land in the allotee" From the foregoing, an allotment of property under customary law means no more than mere permission to the allottee to occupy such land and does not entitled him to a declaration of ownership to such land..$^{45}$

Furthermore, alienation of family property is not common in the communities in the South-East, South-South and North -Central. ${ }^{46}$ According to a recent research conducted by the Nigeria Institute of Advance Legal Studies, it was discovered that data from field research did not capture prevalent instances of alienation of family property. ${ }^{47}$ But, the researcher found that at Iwuru Central Community of Cross River State, family property could be alienated. In this community, the Village Council may give part of the communal land to any one who requests to use it for a project that will bring development to the village. In such instances, communal land may be given to indigenes as well as strangers.

\author{
${ }^{40}$ See footnote 36 above \\ 41 [1908] 1N.L.R. 81 \\ 42 [1986] 2 NWLR (Pt.22) 367 \\ 43 [1985] 3 NWLR (Pt.11) 207 \\ 44 [1988] 2 NWLR (Pt.78) 509 \\ 45 See Ndukwe v. Acha [1998] 6 NWLR (Pt. 552) 25. \\ ${ }^{46}$ E. Azinge Restatement of Customary Law of Nigeria (1 ${ }^{\text {st }}$ ed, 2013, Nigeria Institute of Advance Legal Studies Lagos) at 90 \\ 47 Ibid.
}

INTERNATIONAL JOURNAL OF INNOVATIVE RESEARCH \& DEVELOPMENT 
However, they are expected to present the community with certain traditional rites. In addition, the community may decide to cut and sell part of the communal land. The essence of this act is to generate money for the community to solve communal problems. It is under this kind of situation that outright sale of communal land is encouraged. At Owerri, in Imo state, it has been discovered that the concept of community pledge is recognized as a method of land alienation. Here once the pledge makes a refund, the pledger has an obligation to return the pledged item because once a pledge, always a pledge.

Thus, the concept of family property is indigenous to our society. In Olowosago $v$ Adebanjo ${ }^{48}$ the court held inter alia that the concept of family property is original to our indigenous society and is the bedrock of our laws of inheritance.

\subsection{Ownership of Property under Customary Law}

Generally, a man and a woman can own property under customary law. However, different principles apply to the inheritance of these properties. There is a general consensus across the communities in the South-East, South-West, South-South and North- Central that a man or a woman is capable of owning property under customary law. ${ }^{49}$ For example, the property of a woman is capable of being inherited by her children under customary law. In Amadi v. Nwosu ${ }^{50}$ the court held that the Married Woman Property Act 1882 (a statute of general application in Nigeria) is applicable to marriages contracted and governed by customary law. The effect of this decision is that the capacity of the woman subject to customary law to acquire, hold and dispose of property depending on customary law. In most culture, the husband is excluded from inheriting his wife's properties. Among the Yoruba ethnic group for example, it will be anathema to their custom to allow a husband to inherit his late wife's property. According to Dr Elias. "Rules of inheritance apart, local sentiments would frown upon the ideal of a scapegrace husband aspiring to share in his deceased wife's family property. ${ }^{51}$ Okunlola ${ }^{52}$ state that the idea of a husband inheriting from his wife is repugnant to Yoruba custom and such husband will be ridiculed in the society. However, under Esan Native Law and Custom the position is different. Generally, when a wife dies, her children usually inherit her property. Where she has one child who is already married, the child performs the burial ceremonies and inherits her property. But if the woman has no issue, then the husband inherits her property. ${ }^{53}$ Also, there are restrictions to the kind of property a woman can own under customary law. Among the Ogonis in the present-day Rivers State, a woman cannot own property under customary law. ${ }^{54}$ It is hereby submitted that in the light of the recent judicial pronouncement on the effect of section 42 (2) of the 1999 Constitution, this particular customary law rule ought to be declared as repugnant to natural justice, equity and good consciences, and also inconsistence with the Constitution. Also, among the Oron people of Akwa Ibom state, a woman cannot own a cow. She cannot buy it for herself personally, but she can buy one for her son. In Awka Local Government of Anambra State, a woman cannot own yam barn, goat and Kola-nut tree(s). Ownership of goat is strictly preserved for men. In the case of yams, a woman can own yams; neither can she own a barn.55 Prior before now, in many instances, a woman may not own landed property through inheritance. In Nezianya $v$ Okagbue 56 the court stated inter alia that 'a woman cannot own land as of right in many villages / communities. She only has custody of any piece of land her husband permits her to cultivate or else holds any land in trust for her male children only. However, recent judicial pronouncement has altered this rule of customary law. ${ }^{57}$ The point must be made here that there is nothing precluding a woman from buying a land, which subsequently becomes her personal property to be inherited by her children upon her death. This is a fundamental right guaranteed by the 1999 Constitution as (amended). As I have noted above, generally under customary law no individual has exclusive ownership of family / communal land. Thus, strictly under customary law, family land presupposes perpetual holding boarding on inalienability. That is why such land normally belongs to vast family members of whom many are dead: few are living and countless members are still unborn. ${ }^{58}$ Therefore, where land is held as family land and it is owned by three or more members of a family, it follows that it must continue to belong to the descendant of all the original owner and unless there is evidence that one of the branch has no surviving descendants, a claim for declaration of title by one of the branches against the other cannot succeed. ${ }^{59}$ Generally, among the various communities in Nigeria, there appears to be uniformity in custom that stipulates that a woman cannot own land through inheritance. But she may however acquire ownership through other means e.g. through sale, transfer, gift etc. For example, in Itu Local Government of Akwa Ibom State, ownership of land is determined by who deforested a piece of the land. Under Nigerian land law, this is one of the methods of establishing a claim to land through traditional history. Consequently, a woman who deforested a portion of the land owns that land. Also, in Nnewi in Anambra State, a married woman can own the land she bought and when she dies, the land goes to the youngest of her children and never to her husband. Although it has been said that in some communities a woman cannot own land through inheritance, there exist an exception at Nnewi before the judicial intervention that now makes it possible for women to own land through inheritance as of right when succession issue is being determine. Here, a

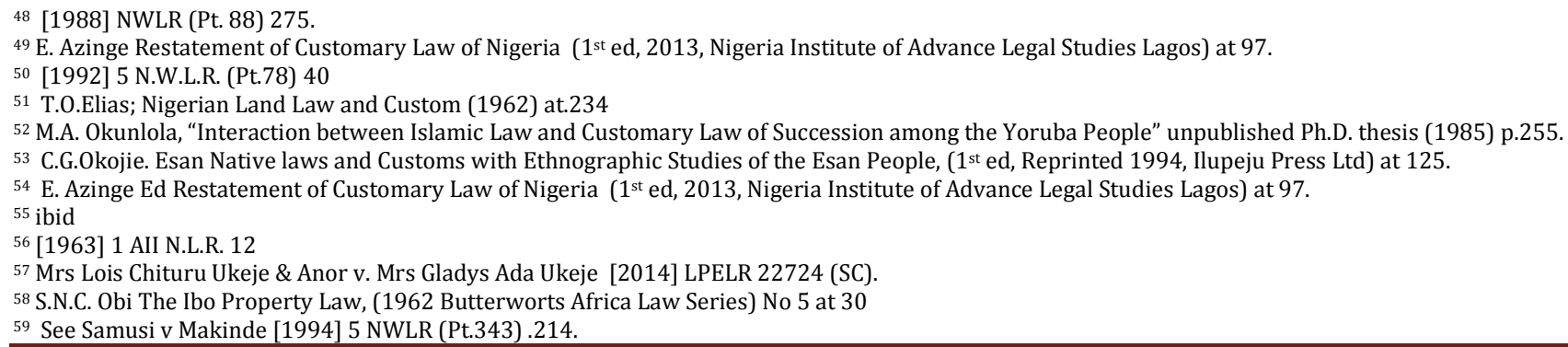


woman in her capacity as a daughter may own land through inheritance. In such situation, she is adopted to stay in the house and bear (male) children for her father. This custom is known as Irachieya / Nrachi custom. 60

Furthermore, it was discovered by the researcher from the Nigeria Institute of Advance Legal Studies that in Aro-Ngwa, Osisioma-Ngwa Local Government Area of Abia State, except in situation of pledge or lease, where a man has pledged or leased a piece of land to a woman, she has no right to land in the village. ${ }^{61}$ From the foregoing, these practices are highly condemnable for they are discriminatory nature. It is however doubtful whether these customs that deliberately exclude women from the ownership of land by inheritance can still be upheld as being valid by our courts having regard to the provisions of section 42(2) of the 1999 Constitution of the Federal Republic of Nigeria (as amended) and numerous case law on the subject. In Okpunor community in Anambra state, no woman from the community can claim land as her own. But there is nothing precluding women from outside the community from buying land in Okpunor and owning it. Once there is proper transfer of title, the land will be recognized as the woman's land. With respect, this practise appears to me as double standard and discriminatory against the women of the community. Why discriminate against your indigenous women?

Women can also acquire land, which has been designated as family property through partitioning and allotment. This practice is common among the various communities of South-East, South-West, South-South and North-Central. However, this practise is more common among the Yoruba of the South-West. Partitioning of family land is a recognized method of vesting ownership of family property to an individual or a unit of a larger family. Thus, it uses to be the held view that once a family member is allotted a portion of the family land, he holds a life interest in the property same as a customary tenant. ${ }^{62}$ In Taylor $v$ Williams ${ }^{63}$ Graham Paul J stated as follows:

"Individual rights of use are simply a life interest. On the death of the individual that interest reverts to the whole family, through by reason of the user enjoyed by the deceased individual during his or her life, the family will generally permit or allow his children to have the same user as their parent had if circumstances of the family and the property admit."

However, it doubtful whether this principle state above is still relevant in view of recent judicial pronouncement. In Chukwudozie Anyabunsi v. Emmanuel Ugunze ${ }^{64}$ IGUH J.S.C observed as follows:

However, allotment of portion of family land to its members not by way of permanent out and out grants, but for farming purposes may confer no more than, mere permission on the beneficiaries to make use of such portion of family land as prescribed. Such allotments, unless contrary intention is established may not amount to family divesting itself of possession of the land involved. Although a family land may be allotted to or farmed by a particular member of a family, such allotment or user of the land by the member of the family concerned is no conclusive evidence of the exclusive possession of the land by the beneficiary. This is because the family members in occupation of the various portions of the family land in the absent of contrary evidence, remains agents through whom the family is in effective legal possession thereof.

Apart from allotment and partitioning, a system of individual ownership exists in Obe-Ugwu community of Enugu State. Here because of the fact that most of the land owned by the community has either been partitioned among family members or sold, there is little or on land left. Individual are therefore compared to seek alternative method of acquiring land that will later become their personal property.

\subsection{Traditional Titles}

Generally, traditional titles constitute intangible property under customary law. Presently, Nigeria is made up of various area traditionally occupied by highly diverse ethnic groups with their very distinct and diverse languages and traditions. There are about 371 (three hundred and seventy-one) ethic groups in Nigeria. However, the three most dominant tribes are Ibo, Yoruba and the Hausa-Fulani. In term of geo-political classification, the Ibo's occupy the SouthEast, the Yoruba occupy the South-West and a combination of other ethic groups occupies the North-Central geo-political region of the country. It has been observed that although traditional structure may differ among these groups, one factor remains that amongst them, they have a recognized ruler who may in turn be subordinate to the ruler of a larger community 65 . However, since the attainment of independence in Nigeria, the traditional institution has lost some considerable amount of influence and power. In some situation, the scope of limit of authority has been reduced by the creation of new kingdoms from the existing one. For example, in the Northern part of the country, the Emirs have lost most of their powers to the government. ${ }^{66}$ It has also been observed that where rulers had previously acquired office strictly through inheritance or through appointment by a council of elders, the government has now increasingly become involved in the process of succession into traditional office ${ }^{67}$ in some situations, the government has merged, increased or split traditional domains. ${ }^{68}$

\footnotetext{
${ }^{60}$ E. Azinge Ed. Restatement of Customary Law of Nigeria (1 ${ }^{\text {st }}$ ed, 2013, Nigeria Institute of Advance Legal Studies Lagos) at 98.

${ }^{61}$ Ibid.

${ }^{62}$ See Adegun v Fagbola [1932] 11 N.L.R. 110

63 [1935] 11 N.L.R. 110.

64 [1995] 6.N.W.L.R. (Pt.401) 255.

${ }^{65}$ See J.K. Thornton Warfare in Atlantic Africa 1500-1800 (1999 London and New York Routledge) cited in E. Azinge (ed) Restatement of Customary Law

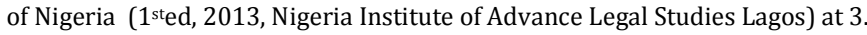

${ }^{66}$ See C. Ewokor "Nigerians go crazy for life" 1 August 2007 BBC News Retrieved 3 September 2010.

67 For example in May 1994, the then Military Head of State Gen. Sani Abacha deposed Awwal Ibrahim, Sakin Zazzau of Suleja Emirate, although he was subsequently reinstated in January 2000.

68 For example there was two rulers of Efik people in the area around Calaber. But in December 1970 it was agreed to combine the office into a single one that was to be held by a ruler known as the Obong. Also by June 2010 Akwa Ibom State had 116 traditional rulers with official certificate from the state.
} They had received new cars on their appointment, among other perks. 
The existence of traditional institutions as a centrepiece for mobilizing people for communal development cannot be over emphasized. Traditional institutions have grown by leaps and bound across the country. This explains the existence of traditional institutions across the 774 local government councils in Nigeria. Thus, because of their link to the people the government uses them as conduits for information dissemination. They also play useful role by resolving communal conflict and indeed service as veritable institution for maintaining law and order in local communities across the country.

Generally, the duration of office of traditional rulers in Nigeria are for a lifetime ${ }^{69}$. However, the tenure of office of traditional ruler can be terminated by the deposition of the traditional ruler. Where this occurs, it is usually done by government of the day upon the misconduct of the traditional ruler. Thus, a paramount ruler is one man having authority over the entire community or kingdom. Usually a person becomes a king, Oba or paramount ruler in Nigeria through two recognized procedures. He could either inherit the throne as of right, having regard to rule of primogeniture or through election consisting of ruling houses. In Benin kingdom for example the tenure of the Oba of Benin is for life. On the death of the Oba, his eldest surviving son ascends to the throne after the performance of the final burial rites in accordance with native law and customs. In Otoro Clan in Abak Local Government Area of Akwa Ibom State the clan headship, paramount ruler ship, village headship, as well as the family headship is for life. The implication of this is that the head cannot be succeeded until he dies or he is deposed. However in some communities, were the village head is found to be guilty of an unpardonable offence; he can be removed from office. ${ }^{70}$ On the other hand, among the communities in South-West, South-South, North-Central and the South-East, researchers discovered that traditional rulers could be deposed by government acting on it own or prompted by the people. ${ }^{71}$ Most of the reasons advanced for the deposition of a paramount ruler includes disobedience to constituted authority, disregarding / disparaging and desecrating of customs and tradition etc. A good example is the deposition of the Deji of Akure land, Oba Oluwadare Adesina. He was deposed because he could not maintain his household, and his relationship with his chiefs and his subject. He, not only maltreated his first wife, but also held his community to ransom by flouting traditional rites, grabbing peoples' land and repeatedly trampling on their civil rights. He was deposed and banished from the throne after Ondo State Government had conducted an investigation that found him guilty. ${ }^{72}$ In Edo State, the Ojuromi of Uromi, His Highness Zaiki Anselem.O. Eidonojie II (JP) was also deposed by the Edo State Government led by the immediate past governor of the state Comrade Adams Aliyu Oshiomhole. The deposition order was contained in a letter dated 9 ${ }^{\text {th }}$ of November $2016 . .^{73}$ The State Government alleged that the deposed Ojuromi committed a lot of offences including fighting one of his subjects Mrs Betty Okoebor after serious altercation on the day of general election in a public field at Uromi, and allegedly travelling abroad without the permission of the governor. Before his deposition, he was suspended for seven day and he was directed to apologise to the state government. The government further alleges that the Onojie refused to apologise hence the deposition. Also, in Igburowo town, Odigbo Local Government of Ondo State, the Akamuja of Igburowo, Oba Akinfesola Adewola was suspended from the throne for allegedly perpetrating various atrocities in the community. Some of the atrocities were fraud, forceful acquisition of land, frivolous litigation over his subjects' properties, assaulting his chiefs, and failure to perform traditional rites. The suspension of the monarch by the Ondo State government came after mass protest by the people of the community who chased the traditional ruler and his family out of the palace, forcing them to trek barefooted for several kilometres. ${ }^{74}$

As noted earlier above, traditional titles constitute intangible property, which is capable of being inherited by the children of the deceased. However, female children are excluded from the inheritance of hereditary traditional titles. This practise is common among most communities in Nigeria. Generally, women are excluded from becoming traditional rulers. The reasons for the exclusion are not farfetched. In most kingdoms and emirate, ascendancy to the throne is exclusively reserved for the male children of the royal families by customary laws, which makes it difficult for women to ascend to the throne. However, there appears to be some exception to this general position from history. Two-monarch queens are on record to have ruled in Ijesha kingdom in the $19^{\text {th }}$ century among the Yoruba of the south-west. Also, at Akure, there is record of regency, which had a very strong affinity with the Ijesha kingdom. In fact, the regency is still been practised at Akure till date. It is on record that the reigns of these two-monarch queens in Ijesha kingdom were remarkable and eventful. They led their army into war against adversary male monarch and defeated them.

Furthermore, most statutes dealing with succession to the traditional stool regulate the class of persons that are illegible to contest for the throne. For example, the Declaration of Customary Law Regulating Succession to Traditional Ruler Title of the Obi of Onicha -Ukwu in Aniocha North Local Government (Delta State of Nigeria Gazette No.8 ASABA 20 ${ }^{\text {th }}$ February, 2003 Vol. 13) adopted in 2003 provide that Succession to the Obi of Onicha-Ukwu stool devolves on the first in rank in the Okpala title society in the town who usually holds the office of the Onihe of Onicha-Ukwu. Under this law, female is barred from consideration ${ }^{75}$. Also, in Edo State, the law that regulate the appointment of a candidate to fill a vacancy in the traditional ruler title is the provision of section 13(1) of the Traditional Rulers and Chief Edict 1979.76 That section provide as follows:

\footnotetext{
${ }^{69}$ E. Azinge Restatement of Customary Law of Nigeria (1 ${ }^{\text {st }} \mathrm{ed}, 2013$, Nigeria Institute of Advance Legal Studies Lagos) at10.

70 This is the position at Iwuru Central Akampka Local Government Area of Cross River State.

${ }^{71}$ E. Azinge Restatement of Customary Law of Nigeria (1 ${ }^{\text {st }}$ ed, 2013, Nigeria Institute of Advance Legal Studies Lagos) at 11.

72 The Ondo State Government led by Dr Olusegun Mimiko deposed Oba Oluwadare Adesina on The 10th June 2010. He was banished and order not to step into Akure for six months. See Daily Champion (Lagos) “ Nigeria: Wife Bashing -Deji of Akure Deposed, Banished. Available at www.alafrica.com (last accessed on the $4^{\text {th }}$ July 2018 ).

73 See " Tension in Edo over the deposition of Uromi monarch “ in The Pilot available at www.nigerianpilot.com (last accessed on the $4^{\text {th }}$ of July 2018).

${ }^{74}$ E. Azinge Restatement of Customary Law of Nigeria (1 ${ }^{\text {st }}$ ed, 2013, Nigeria Institute of Advance Legal Studies Lagos) at 12.

75 Ibid at page 14.

${ }^{76}$ Edict No 16 of 1979
}

INTERNATIONAL JOURNAL OF INNOVATIVE RESEARCH \& DEVELOPMENT

DOI No. : 10.24940/ijird/2018/v7/i8/ 131085-317209-1-SM 
A person shall, unless he is disqualified under sub-section (2) of this section, be qualified to be a candidate to fill a vacancy in a traditional ruler title if: -

- He is proposed by a ruling house or the person having the right to nominate candidate are entitled to propose according to customary law as a candidate;

- He is a person whom the ruling house or the person having the right to nominate candidates are entitled to proposed according to customary law; or

- He is unanimously proposed as a candidate by the member of the ruling house or the person entitled to nominate candidate.

- Where the succession is based on age, he is the oldest person qualified in accordance with customary law to succeed to the title;

- Where a hereditary system of succession operates he is the person entitled under customary law to succeed to the title.

From the above provisions, it clear that under section 13(1)(d) of Edict No 16 of 1979 it is impossible for a woman to qualify as a person entitled under customary law, when in fact $a b$ initio she is already disqualified under customary law ${ }^{77}$. In Ondo State, with respect to the throne of Ondo, to become an Osemawe, i.e the Oba, the position maybe held by any man whose father ruled, and not necessary only by sons born on the throne. Here no son can directly succeed his father because of the existence of other ruling houses. However, this is not the position with the Oba of Benin kingdom, which is based purely on the rule of primogeniture. The same rule applies to other kingdoms within Edo State. Among the Yoruba, an exception to the practise of rotating the kingship among the ruling houses is found in Oyo kingdom. Here succession to the Alaafin of Oyo throne is purely based on the rule of primogeniture. Here, the eldest male offspring of the deceased Oba known as Aremo (heir apparent) succeeds incontrovertibly to the throne as the next Alaafin of Oyo.

At Oron nation in Cross Rivers State, a woman cannot hold Oron National Titles such as Ikpoto Oro and Akpah Oro. However, there nothing stopping a woman from being conferred with titles such as Ikeyo Oro. In Benin kingdom women cannot hold hereditary chieftaincy titles such as Oliha, Edohen, Ezomo, Iyasele, Oloton and Ero. The same goes for the Esan tribe. Succession to the throne of the Oba of Benin is exclusively preserved for the crown prince after the performance of the burial rites of the late Oba. Here, the principle of primogeniture is highly observed and respected. This same situation applies to the Esan speaking people of Edo State. It is noteworthy to remark that because of the existence of the customary rule of primogeniture that regulate succession to the throne in Esan land, it has become difficult for the government of Edo State to announce a replacement to the deposed Onojie of Uromi after a year. However, on the 9th of May 2018, the current Executive Governor of Edo State Mr Godwin Obaseki reinstated the deposed Onojie of Uromi, his Royal Highness Anselm O. Aidenojie JP, who was deposed by the administration of Governor Adams Oshiomhole in $2016 .{ }^{78}$ Also, among the Abriba people of the South-East succession to the Ezeship is by inheritance based on the principle of primogeniture. Thus, where the deceased is a titled person, his first son takes over his father's title. In some community, a distinction is made between a biological son and an adopted son when it concerns succession. At Ibadan in the south-west this distinction is noticeable. It is their custom that an adopted child cannot become a king or a chief within the family or community. This custom directly confronts the provision of section $42(2)$ the 1999 Constitution. It is submitted that if the validity of this custom is challenged in court, the court will certainly declare it incompatible with the aforesaid constitutional provisions. A similar custom is also found among the people of Iwo. At Iwo, an adopted child is not entitled to chieftaincy rights within the family of the person who adopted the child.

From the foregoing, it is clear that chieftaincy property constitutes properties, which may be inherited upon the death of the traditional titleholder. In certain circumstances, females may be excluded from inheriting these titles. However, the inheritance of such traditional titles may bestow upon its beneficiary certain rights under native law and custom. ${ }^{79}$ In Ogiamen v. Ogiamen ${ }^{80}$ the Supreme Court affirm a rule of Benin customary law to the effect that within Bini chieftaincy families, the eldest son who inherits the chieftaincy take all the property of the deceased.

\section{Nature of Succession under Customary Law}

The principle of inheritance and succession constitute a vital part of the Nigeria society both under the more formal system of law (i.e. statutory laws) and more importantly under customary law. ${ }^{81}$ According to A.A. Kolajo ${ }^{82}$ "Succession is the devolution of the title to property under the law of descent and distribution. It is the transmission of property vested in a person at his death to some other person or persons. In common parlance succession means inheritance". However, the word Inheritance and Succession are twin words in the English dictionary but they are in no way 'Siamese' twins. The distinction between the two is profoundly significant in customary law. ${ }^{83}$ Succession has been defined as the act or right of legally or officially taking over a predecessor's office, rank, or duties. It also means the acquisition of the rights or property by inheritance under the law of descent and distribution. ${ }^{84}$ Therefore, inheritance is an estate or property that a man acquired by descent and can be transmitted to his heir in the same way on his death on

\footnotetext{
77 See Sec.13 (2) of Edict No 16 of 1997 for the grounds for disqualification of a person for a traditional ruler title.

78 For further reading see Obaseki reinstates deposed Onojie of Uromi at: https://www.vanguardngr.com/2018/05/obaseki-reinstates-deposed-onojieuromi-aidonojie/ (last accessed on the $24^{\text {th }}$ of June 2018).

${ }^{79}$ E. Azinge. Restatement of Customary Law in Nigeria (1 ${ }^{\text {sted }} 2013$, Nigerian Institute of Advance Legal Studies Lagos) at103. 80 [1967] 1ALL NLR 191.

81 E. Azinge Restatement of Customary Law in Nigeria (1 ${ }^{\text {ste }}$ 2013, Nigerian Institute of Advance Legal Studies Lagos) at 104

82 A.A. Kolajo Customary law in Nigeria through cases (Revised ed 2001, Spectrum Books Limited.) at156

83 A. Emiola Emiola's African Customary Law (3 ${ }^{\text {rd }}$ ed 2011, Emiola Publisher Limited) at 177.

84. A.G Bryan. Black's Law Dictionary ( $9^{\text {th }}$ ed, for the iPhone/iPad/iPod touch version 2.1.2 B13195) at.1569.
}

INTERNATIONAL JOURNAL OF INNOVATIVE RESEARCH \& DEVELOPMENT DOI No. : 10.24940/ijird/2018/v7/i8/ 131085-317209-1-SM 
intestacy. While on the other hand, succession has a broader meaning. It means the acquisition of rights upon the death of another. Thus, the word encompasses that which in English law are governed by three different rules of law i.e. the law of Wills, the law of intestacy, and the law relating to accession to title and dignities. All these also have parallels in customary law. ${ }^{85}$ Consequently, inasmuch as the word succession embraces customary deathbed declarations, inheritance of property and succession to office and dignity/ titles; there is no other regime of law in which its adoption is more appropriate than under customary law. In it simplest meaning, succession is the substitution of a living person for the deceased person in relation to all the right and duties which the latter had.86 It therefore means that inheritance and succession are the principles that govern the transmission of property tangible or intangible of a deceased person to some other person(s). ${ }^{87}$ Usually, a common principle of inheritance is that "succession" is an inherent and inalienable right and not by appointment. ${ }^{88}$ In Nigeria, there are two systems of law that is recognised that regulate the disposition of property upon the death of a person. These systems are known as testate and intestate succession. Testate succession involves the disposition of property under the Wills Act and in accordance with the various Wills Law of the different states of the federation. In Nigeria, there is no uniformity of laws applicable to will. ${ }^{89}$ In the old Western Region from where the old Bendel State was created from, the applicable law was the Wills Law..$^{90}$ Most of the state created from the former Western Region adopted this Wills law. For example, Lagos State adopted the Western Nigeria Law by the Applicable Laws Edict of $1972 .{ }^{91}$ In the rest of the country, i.e. the Northern and the Eastern States, the situation is quite different. Whilst some state created from the former Western Region have enacted their individual laws on Succession, which are basically a reproduction of the Western Nigeria Wills law, in the rest of the country where there are no local legislations regulating wills, then the applicable law in such states is the English Wills Act of 1837, which is a Statute of General Application in Nigeria $^{92}$ and also the Wills Amendment Act 1852. Furthermore, although the Wills Law of the former Western Region substantially re-acts the Wills Acts 1873 and 1852, and the Wills (Soldiers and Sailors) Act 1918, there are two significant provisions of the Western Nigeria Law, which are not derived from the English Act. They are as follows:

- By section 3(1) of the law, real and personal estate, which cannot be affected by testamentary disposition under customary law, cannot be disposed of by will. This is very relevant in relation to un partitioned family property.

- While the general rule that a will is revoked by the subsequent marriage of the testator is retained, customary marriages are however excluded from having this effect ${ }^{93}$.

Under this system, the intention of the deceased is given effect to as contained in the will subject however to the fulfilment of the conditions for it validity under the law. ${ }^{94}$ On the other hand, intestate succession basically involves the application of three systems of laws. These are the common Law; the Administration of Estate Laws of the various State and the Customary law. ${ }^{95}$ The patterns of intestate succession under customary law in Nigeria have many variations, as there are ethnic groups in the country. ${ }^{96}$ Although marriage creates a contractual relationship between the parties, its validity and consequent rights is dependant on law. In countries where there are multiple systems the implication is that there are different kind of marriages and there is substantial asymmetry between these attendant rights. In other words, the type of marriage that a couple contract determines the rights, such as succession that is attached to such marriage ${ }^{97}$. As noted earlier, the customary law regulating inheritance and succession like every aspect of customary law in Nigeria differ from one locality to another. In other words, different laws govern the principles of inheritance and succession depending on the community. Thus, the customary law that should be applied in a particular circumstance would be the customary law of the deceased irrespective of the place where he died. This is so even when the deceased died while residing outside his home state or community and he left behind landed properties in these places. In this context, the personal customary law of the deceased shall apply to the distribution of his landed property outside his community. Thus, the lex situs rule under Nigeria land law is displaced. Therefore, once the issue(s) touches on causes and matters arising from inheritance, the appropriate customary law should be the customary law applying to the deceased..$^{98}$ Although there appears to be differences in the customs of most of the ethnic groups concerning succession, it is important to also mention that regardless of these differences, certain characteristics are shared amongst these ethnic groups. For instance, it is common for the rules of customary law governing inheritance to be displaced where there is a valid will left behind by the deceased. ${ }^{99}$ Also, in some ethnic group, certain rules of customary law are very sacrosanct and cannot be disregarded by a testator while making his will. These principles of customary law have enjoyed statutory

\footnotetext{
${ }^{85}$ See note 12 above at $\mathrm{p} .177$.

${ }^{86}$ M. Okunola Relationship between Islamic Law and Customary law of Succession in Southern Nigeria in B Ajibola (ed) Toward the Restement of Nigerian Customary Law (1991 Federal Ministry of Justice Lagos) at 158.

87 D.H Parry The Law of Succession: Testate and intestate (1972 Sweet and Maxwell Ltd London) at 1

${ }^{88}$ R.A.I Ogobobine Materials and Cases on Benin Land Law (1978 Bendel Newspapers Corporation, Benin City) at 36.

${ }^{89}$ I. E Sagay Nigerian Law of Succession; Principles, Cases, Statutes and Commentaries ( $1^{\text {st }}$ ed, 2006, Malthouse Press Ltd, Lagos) at124. See E.I. Nwogugu

Family law in Nigeria (2011 HEBN Publication Ibadan) at 372; see also M.C. Onokah Family Law (2000 Spectrum Books Limited, Ibadan) at 317.

${ }_{90}$ Cap.133 laws of Western Region of Nigeria, 1959.

91 No 11 of 1972.

92 Thomas v. De Souza [1929] 9.N.L.R. 81.

${ }^{93}$ I. E. Sagay Nigerian Law of Succession; Principles, Cases, Statutes and Commentaries (1 $1^{\text {st }}$ ed, 2006, Malthouse Press Ltd, Lagos) at 124.

${ }_{94}$ See for example Section 9 of the Wills Act, 1837 and Section 6 Wills Law, 1958.

95P.O. Itua "Succession under Benin Customary Law in Nigeria; Igiogbe Matters Arising" 2011 Vol. 3(7) Journal of Law and Conflict Resolution Page 117-

129. Available online at http://www.academicjournals.org (last Accessed $6^{\text {th }}$ July 2018).

${ }_{96}$ E.I. Nwogugu Family law in Nigeria (2011 HEBN Publication, Ibadan) at 399.

${ }^{97} \mathrm{~K}$ Akua "Women, Marriage and Intestate Succession in the context of legal pluralism in Africa" being a paper delivered at the 23 Brigitte M. Bodenheim lecture on family law at the UC Davis School of Law in January 2006.

${ }^{98}$ I. E. Sagay Nigerian Law of Succession; Principles, Cases, Statutes and Commentaries (1 ${ }^{\text {st }}$ ed, 2006, Malthouse Press Ltd, Lagos) at 257. See also Tapa $v$ Kula [1945] 18 N.L.R. 5.

${ }_{99}^{9}$ T.O. Elias Nigerian Land Law and Custom.
}

INTERNATIONAL JOURNAL OF INNOVATIVE RESEARCH \& DEVELOPMENT

DOI No. : 10.24940/ijird/2018/v7/i8/ 131085-317209-1-SM 
protection and judicial recognition. For example, the provisions of section 3(1) of the Will Law of Bendel State, ${ }^{100}$ provides as follows:

Subject to any Customary law relating thereto, it shall be unlawful for every person to devise, bequeath or dispose of, by his will executed in a manner hereinafter required, all real and all personal estate which he shall be entitled to either in law or in equity, at the time of his death and which if not so devised, Bequeathed and dispose of would devolve upon the heir at law of him, or if he Become entitled by descent of his ancestor, or upon his executor or administrator.

By this provision, a rule of Benin customary law that entitled the eldest surviving son of the deceased to inherit his late father's Igiogbe ${ }^{101}$ was preserved. The effect is that failure by the testator to take cognizance of this section will in validate any bequest in this will that this provision affects. ${ }^{102}$ Regarding the effect of these provisions in our legal jurisprudence has lead to the rise of two conflicting views as to the true meaning of this provision of the Wills law in Edo State. Accordingly, two schools of thought have emerged each trying to postulate as to the true meaning and in port of the section of the law. One school of thought holds the view that the phrase "subject to customary law relating thereto" in the section is a qualification of the testator's testamentary capacity, rendering any purported disposition of property by will which is inconsistence with customary law, null and void. They postulated further that "Customary Law" here includes the rule of intestate succession under customary law ${ }^{103}$. Thus, the provisions of section 3(1) of the Will law of Bendel State now applicable in Edo State has tactically removed the freedom of testamentary powers from a testator in the State. On the other hand, the opposing school holds the view and argued that the law did not remove freedom of testamentary powers, and that what the law sought to achieve, was to only restrict freedom of testamentary power of a testator in Edo State, no more no less! They argue further that the views expressed by the other school of thought is ridiculous, because the intention of the Will's Law was to confer testamentary power in a society in which everybody was subject to one type of customary or another. However, Prof. Itse Sagay has argued that it would be wrong to conclude that a testator in Edo State does not possess freedom of testamentary powers to make a will. According to the learned professor "It is therefore clear that section 3(1) does not in anyway restrict testamentary capacity; it merely defines the type of property which may or may not be disposed of by will, the latter being property which under customary law does not belong exclusively to the testator." 104 Thus from the foregoing, the right of the deceased to make a testament is limited only to a portion of his estate as the deceased must bequeath the Igiogbe to his eldest surviving son. ${ }^{105} \mathrm{He}$ can not derogate from the law, otherwise that portion of his will would be declared null and void and of no effect. The affected property would be return to the beneficiary owner under customary law. ${ }^{106}$

Over the years, there has been this nagging question boarding on the correct position of the law concerning the status of a deceased customary law where the deceased has lived in a different ethnic group for such a long time to be considered as haven adopted their way of life. Situations like this could raise intractable difficulties in certain situation concerning the appropriate customary law to be applied. ${ }^{107}$ For instance, how does one determine the customary law of a person that has lived in a foreign land outside his ethic group for so long and has adopted the life style / custom of his new community? In trying to answer this question, that has eluded some legal writers for some time in the past, some writers and legal analyst were tempted to suggest, following the previously held view that the deceased person carries his customary law with him to his new place of aboard before his demise, that the appropriate customary law was the deceased personal customary law. Consequently, under such situation they argue that it was legally impossible for the deceased to change his customary law at will. In other words, a person dies with his initial customary law he acquires at birth as a member of his ethnic group. This previously, held view that a person carries his original customary law he acquired at birth with him anywhere he goes is no longer the correct position of the law; this view has since been discarded since the celebrated case of Adeniyi Olowu \& Ors v. Olabowale Olowu \& Ors. ${ }^{108}$ Here the Supreme Court held that a person belonging originally to one ethnic group could by a process involving time, association, marriage, personal wishes and manner of life become assimilated into and thereby legally acquire the status of another ethnic group. In other to able to properly appreciate this landmark decision, it is important to take a look at the state of our law before the decision in Olowu's case. Prior to the decision in Olowu's case the judicial authority on the applicability of the lex loci or lex fore to "non-natives" can be best be illustrated with these two cases. In Osuagwu v Soldier ${ }^{109}$ a dispute arose between two Ibo men living in Kano. The Court has to consider whether to apply Islamic law, which was the lex situs and lex loci or Ibo customary law, which was the parties' personal law. Declaring its preference for the latter in the interest of justice, the court stated as follows:

We suggest that where the law of the court is the law prevailing in the area but a different law bind the parties, as where two Ibos appear as parties in the court where Moslem law prevails; the native court will...in the interest of

\footnotetext{
100 Cap 172 Laws of Bendel State applicable to Edo State.

101 This is the principal house were the deceased live and died, but not necessary where he was buried. For further definitions and meaning, see the case of Ogiamien v Ogiamien [1967] NMLR 247 and Idehen $v$ Idehen [1991] 6 N.W.L.R (Pt198) 382.

102 See Lawal-Osula v. Lawal-Osula [1993] 2NWLR (Pt.274) 158.

103 I. E. Sagay. Nigerian Law of Succession; Principles, Cases, Statutes and Commentaries (1 ${ }^{\text {st }}$ ed, 2006, Malthouse Press Ltd, Lagos) at 142

${ }^{104}$ I.E. Sagay "Customary Law and Freedom of Testamentary Power" (1995) Vol. 39(2) Journal of African law Cambridge University Press. Available on line at http;//www.Jstor.org (last Accessed $8^{\mathrm{TH}}$ July 2018).

105P.0 Itua "Succession under Benin Customary Law in Nigeria; Igiogbe Matters Arising" (2011) Vol3 (7) Journal of Law and Conflict Resolution Page g 117.129. Available online at http://www.academicjournals.org (last accessed $10^{\text {th }}$ July 2018).

106 See Lawal-Osula v. Lawal-Osula [1993] 2NWLR (Pt.274) 158. See also Idehen v Idehen [1991] 6 N.W.L.R. (Pt198) 382

107 I. E Sagay. Nigerian Law of Succession; Principles, Cases, Statutes and Commentaries (1 ${ }^{\text {st }}$ ed, 2006, Malthouse Press Ltd, Lagos) at 258.

108 [1985] 3.NWLR (Pt.13) 372

109 [1959] N.R.NL.R. 39
}

INTERNATIONAL JOURNAL OF INNOVATIVE RESEARCH \& DEVELOPMENT

DOI No. : 10.24940/ijird/2018/v7/i8/ 131085-317209-1-SM 
justice...be reluctant to administer the law prevailing in the area, and if it tries the case at all ...in the interest of justice...choose to administer the law which is binding between the parties ${ }^{110}$

Furthermore, in AyisatuTapa \& Ors v. Yanrata Kuka.111 A Nupe Moslem from Bida in the present-day Niger State died intestate in Lagos leaving property in Lagos. The Court held that the law applicable to the distribution of his property was his personal law, which was the Moslem law prevailing amongst the Nupe of Bida and not the law that applied in Lagos. Thus, from the foregoing, it clear that in certain circumstance the most appropriate law of a deceased may be his personal law that was assumed to follow him everywhere he goes before his demise. This of course used to be the position before the celebrated case of Adeniyi Olowu \& Ors v. Olabowale Olowu \& Ors. ${ }^{112}$ However, Prof. Sagay has argued that in certain circumstance, its applicability can be unfair, unjust and inconvenient to apply the "carried over" personal law in preference to the customary law of the parties' domicile, or the law of the place of the transaction. He posited that the lacunae in the law appeared to be two-fold: (1) a definition of circumstance in which the personal law or lex patriae could be excluded in favour of other system of law like the lex domicile, lex situs, lex loci or lex fori; (ii) a definition of the circumstance in which one personal law could be dropped and another one acquire. ${ }^{113}$ In other to overcome these gaps, he recommended the views of Bello J. (as he then was) in the case of Yinusa v Adebusokan ${ }^{114}$ where the learned Judge held as follows:

Subject to any statutory provision to the contrary, it appears... that mere settlement in a place, unless it has been for such a long time that the settler and his descendants have merged with the native of the place of settlement and have adapted their ways of life and custom, would not render the settler or his descendants subject to the native law and custom of the place of settlement

This view, which was stated above so many years ago by Bello J has been confirmed and enlarged by the Supreme Court in the case of Olowu $v$ Oluwu. ${ }^{115}$

\subsection{Patrilineal Inheritance}

Patrilineal inheritance is a system whereby property is inherited from one's father or another paternal ancestor $^{116}$. This system is also known as patrimony. ${ }^{117}$ This system is a very common feature of our customary law in Nigeria. It has been observed that where this system of inheritance is practised, the intention of the custom is to ensure that property remains within the family from generation to generation. Apart from the above stated reason, this system of inheritance seeks to ensure that family identity and traditions are maintained ${ }^{118}$. With regard to chieftaincy titles, which are hereditary, they can only be inherited through patrilineal mode of inheritance. However, in many instances of patrilineal inheritance, male children inherit to the exclusion of the female children. But there is limited situation were female children are part of patrilineal inheritance. In such instances, a distinction is drawn between family property and personal property of the deceased. 119

Thus, among the various communities of South-East geopolitical zone, consisting of mainly Ibo speaking ethic groups and those of the South- South geopolitical groups particularly the Esan, Benin and other groups within Edo State, inheritance through patrilineal is mainly based on the principle of primogeniture. ${ }^{120}$ This is also the position among some communities in Delta State. ${ }^{121}$ On the other hand, among the Yoruba ethnic group of the Southwest patrilineal inheritance is based on the nature of the property. One distinctive characteristic of this system is that female children are not excluded from inheritance, whereas under the principle of primogeniture female children are excluded.

\subsection{The Rule of Primogeniture.}

According to Black Law Dictionary ${ }^{122}$ primogeniture means "the state of being the first-born child among sibling". It also means the common law right of the firstborn son to inherit his ancestors' estate usually to the exclusion of younger siblings. Thus, in ordinary parlance, primogeniture is defined as the system in which the oldest son in a family received all the property when his father dies. ${ }^{123}$ These definitions aptly described the nature of primogeniture inheritance under customary law in Nigeria. In most communities where this system of inheritance is practised, the primogenitor does not only inherit the property of his deceased father, but also in most instances also inherit the duties of his father particularly with respect to catering for other children; most especially the women in the family who stand no chance of inheritance. It has been observed that within this specific nature of primo genitive inheritance, there are significant variations among different ethnic groups and also even within the same ethnic configuration. ${ }^{124}$ For example, among the Ibo speaking communities of South-East, the eldest son becomes the head of the family on the death of his father. The property of his late father is vested in him to hold in trust as a caretaker of the family property on behalf of the rest members of the

\footnotetext{
110 [1959] N.R.N.L.R. 39 at 41.

111 [1945] 18 NLR 5

112 See footnote 108 above.

113 I.E. Sagay Nigerian Law of Succession; Principles, Cases, Statutes and Commentaries (1 ${ }^{\text {st }}$ ed, 2006, Malthouse Press Ltd, Lagos) at 260.

114 [1968] N.N.L.R. 97,

115 [1985] 3. N.W.L.R. (Pt.13) 372

116 R.A. I. Ogobobine, Materials and Cases on Benin Land Law at 190

117 Oxford Dictionary of English (ODE) Second Edition revised (2005 Oxford University Press). iPhone version.

118 R.A. I. Ogobobine, Materials and Cases on Benin Land Law at 179.

119 E. Azinge. Restatement of Customary Law in Nigeria (1 $1^{\text {st }}$ ed, 2013, Nigerian Institute of Advance Legal Studies Lagos) at111.

$120 \mathrm{Ibid}$ at 107

121 See Oke \& Anor v. Oke \& Anor [1974] ALL NLR 401.

$1229^{\text {th }}$ Edition for iPhone/iPad/iPod touch. (2009-2013).

123 E. Azinge Restatement Of Customary Law In Nigeria (1 ${ }^{\text {st }}$ Ed, 2013, Nigerian Institute Of Advance Legal Studies Lagos) At107.

124 Ibid At 108.
}

INTERNATIONAL JOURNAL OF INNOVATIVE RESEARCH \& DEVELOPMENT 
family. In Edo state, where the principle of primogeniture is fully operational, there is a shape variation in the practise of the system between the Edo speaking communities in the state with their Esan counterpart within the same state.

Among the Esan, the rule is applied in it purest state. Thus, amongst most communities in Esan land, the eldest son is vested with total right to inherit all the properties of his deceased father after the performance of the funeral rites. According to Dr C.G. Okojie:

"Basically, the first son inherited the father's property and sheared to any of his junior brothers and sisters at his pleasure. It is true that some brothers particularly the second and the third could challenge his unfairness in taking everything to himself and reported the matter to the Egbele. ${ }^{125}$ In this, the Egbele could only advice, they could not force the first son to part with what has come to him by right." 126

It's my humble view that this rule of customary law is unfair to the other children of the deceased. Although customary law places a responsibly on the eldest son to take adequate care of his younger sibling, cases abound where this responsibility has been abandoned by irresponsible first sons and there is no remedy provided by the customary law to adequately address these problems. For equity sake, there must be some form of distribution with the other children of the deceased. Also, this rule of customary law is discriminatory in nature, particularly towards the female children of the deceased. In other to do equity among the children of the deceased, I here by proposed that the eldest surviving son such inherit the ijiogbe, (the principal house where the deceased lived while he was a live) while the other properties can be shared among the other children with the eldest son exercising the option to choose first. Apart from the practise stated above, it is very important to mention the practise in some communities in Esan land regarding the interpretation of the customary rule of primogeniture as it affects inheritance. In some communities, the property of the deceased is shared according to the number of Ukuede $e^{127}$ the deceased person has. Whereas among the Binis', there is a qualification to the nature / type of property the eldest son can inherit absolutely, ${ }^{128}$ however among the Esan, the reverse is the case. In Benin once the eldest son inherits the Igiogbe, which is the principal house where the deceased lived in his lifetime, the remaining children are entitled to share in the estate of the deceased. This customary law rule has attained judicial notoriety in a number of cases. ${ }^{129}$ Thus it is a well-established rule of customary law of inheritance and succession among the Binis that the eldest surviving son of the deceased inherits the house where, the deceased lived in his lifetime and not necessarily where he died which is called the Igiogbe, after the performance of the final burial rites. As noted earlier above, one of the striking features of this system is that it is male dominated. Thus, among the Ibo speaking ethnic group in the South-East and the Binis in the South-South, male member of the family benefit to the disadvantages of the female children. In particular as it affects the Esan speaking communities in Edo State, Dr Okojie reinstated the custom of the Esan people as follows:

Let it be understood at the onset that it was a basic Esan law and custom that when a man dies his property and all he possessed were inherited by his children in the first instance. If he had no children then the right to inherit his property passed to his maternal brothers. If he had no such brother then eldest paternal brother was the next in line of inheritance failing to have children, maternal brother and paternal brother, the right to inheritance passed to Ominjiogbe of the Uelen. This Ominjiogbe might be his uncle or a cousin. ${ }^{130}$

What Dr Okojie described above as the custom of the Esan people is also common among some communities in Ibo land. In such communities, the practice is that if a man dies leaving a male child, the property belongs to the male child. If on the other hand the deceased has no male child, his brother will inherit the property. If the male issue who survives the father dies without leaving any male child behind, the father's brother will inherit the property. If a man dies and subsequently his only son and brother dies, where the late brother has sons, the first son of the late brother will inherit all the property. This custom is what is referred as Oli- Ekpe among the people of Nnewi. ${ }^{131}$ This custom has been seriously criticized for been very discriminatory in nature particularly against the female children. ${ }^{132}$

\subsection{Origin of the Rule of Primogeniture in Benin Kingdom}

The origin of the rule of primogeniture in Benin Kingdom is of historical importance. The customary law rule of primogeniture is otherwise known as the law of hereditary succession or the law of Arevbukhu. ${ }^{133}$ It is the succession law, which provide firstly, that the eldest son of the incumbent ruler or titleholder succeeds the deceased, and that failing as in the case of a heirless incumbent, it is seconded to the next of kin. ${ }^{134}$ According to Dr O.S.B. Omoregie what is define as the "next of kin" may be traced from the next oldest paternal brother, through the next oldest paternal uncle to the next oldest in the degree of paternal cousin. ${ }^{135}$ However, the implication of a next of kin succeeding to title and property is that he immediately begins a new line of succession for his family, except if there is a failure by hairlessness. Legal historian has asserted that the effectiveness of this rule of customary law has largely contributed to the solidarity of the Benin

\footnotetext{
125 Elderly Male Members Of His Extended Family.

126 C.G.Okojie. Esan Native And Custom With Ethnographic Studies Of The Esan People, (1 1 st Ed, Reprinted 1994 Ilupeju Press Ltd) At 119.

127 Means Gate. I.E Representing The Number Of Wives The Deceased Person Married While Alive. In Benin, The Word Is Urho.

${ }^{128}$ P.0 Itua "Succession Under Benin Customary Law In Nigeria; Igiogbe Matters Arising" (2011) Vol. 3(7) Journal Of Law And Conflict Resolution Page 117-142 Available Online At Http://Www.Academicjournals.Org (Last Accessed $12^{\text {th }}$ July 2018).

129 See The Following Cases. Idehen V. Idehen [1991] 6 N.W.L.R. (Pt.198) At 382; Ogiamien V. Ogiamien [1967] Nmlr 247; Lawal -0sula V. Lawal -Osula [1993] 2n.W.L.R. (Pt.274) 158 And Agidigbi V. Agidigbi [1992] N.W.L.R. (Pt. 221) 98

${ }^{130}$ C.G.Okojie. Esan Native And Custom With Ethnographic Studies Of The Esan People, (1 1 st Ed, Reprinted 1994 Ilupeju Press Ltd) At 119.

${ }^{131}$ E. Azinge. Restatement Of Customary Law In Nigeria ( $1^{\text {st }}$ Ed, 2013, Nigerian Institute Of Advance Legal Studies Lagos) At 109.

132 See Particularly The Judgement Of Niki Tobi Jca (As Then Was) In Mojekwu V Mojekwu [1997] 7.N.W.L.R. 238

${ }^{133}$ O.S.B. Omoregie "How the Primogeniture law became Royal in Benin" (2003) Vol. 1(4) in ISPU Newsletter at 7.

134 Ibid

135 Ibid
}

INTERNATIONAL JOURNAL OF INNOVATIVE RESEARCH \& DEVELOPMENT

DOI No. : 10.24940/ijird/2018/v7/i8/ 131085-317209-1-SM 
Monarchy over the past ten centuries since it founding in about 900AD. Thus, since the introduction of the primogeniture law the succession system in the Benin Monarchy has been effectively standardised, and it has been a considerable asset to the political and cultural development of Benin Kingdom. It has guaranteed an age-long traditional discipline both in royal practice and in its subordinate political units. ${ }^{136}$

It is on record that the practise of succession by Arevbukhu is one of the Asegbere types of succession that the Benin traditional system has experimented with over the years. In fact, according to Dr Omoregie, this system of Arevbukhu is the most recent of the types at the monarchical level and one that has been found to possess the greatest quality, especially as it is one that is practice at the highest level.

\subsubsection{The Development of the Primogeniture Law or Arevbukhu in Benin Kingdom}

Historically, the development of the primogeniture law or Arevbukhu as a basis of monarchical succession in Benin started with the effort of Ogiso Igodo, the first king and the founder of Benin Kingdom. ${ }^{137}$ He was the Oba that initiated the move to elevate the succession principle of the Urho ${ }^{138}$ system to the monarchical level over and above the practice of Okaegbee system in the choice of the Odionwere. Ogiso Igodo was able to lay claim to the throne because he claimed that his authority was from Sky-God (Iso) and on the basis of which he took the royal title. Thus, Ogiso then became the title, which was used by all the thirty-one kings of Benin that ruled before the coming of the Oba era in the $13^{\text {th }}$ century. Dr Omorigie further stated that Ogiso Igodo's effort at elevating the Urho principle to the monarchical succession practice lasted only during the period of Igodomigodo (900-1000 AD) before it collapsed. According to him, three factors have been attributed to the collapse of the primogeniture system at the end of the $10^{\text {th }}$ century AD.

Firstly, the system failed because it did not made provisions to take care of a situation where there is an heirless incumbent on the throne. In other words, there was no safeguard for how the succession question was to be resolved if a king does not have an heir to succeed him. This was the situation that Ogiso Orire found himself. There was no provision for the right of the next of kin, as it was later defined to stabilise the succession system. Secondly, similar Arevbukhu provisions did not safeguard the position of the kingmakers. Finally, the mutual responsibility between the king and the kingmakers to preserve the other's primogeniture practice was not defined. Therefore, without these three factors, it was impossible to guarantee the continued operation of the primogeniture law especially as Igodo's elevation of the Arevbukhu principle to monarchical succession practise, and this did not augur well with the envious Edionwere in the village and the senior nobles in the royal council.

However, for a period of two generations (1000-1050AD) the primogeniture law was rejected, and the Odionwere rotational process of succession was applied to the monarchical system. ${ }^{139}$ During this period, the Odionwere who was the oldest senior noble in the royal council, ruled as the Ogiso. One common problem with this era was that majority of the Odionwere were senile because of their age. This was why their era was generally referred to in the history of Benin Kingdom as the era of "DO Nothing Ogiso". Their period was characterised with no major significant achievement in the Kingdom.

By 1050 AD, there was a revival of the primogeniture law in Benin Kingdom. A Royal Decree came into effect that effectively took steps to correct the three factors that has hitherto contributed to the failure of the system at the earlier stage of it introduction. This was achieved during the reign of Ogiso Oriagba (1050-1070 AD). ${ }^{140}$ From the period of the royal decree till date, Ogiso's Oriagba primogeniture decree has never been suspended in the Royal Benin Succession System. Scholars in Ubiniology agrees that this decree proved a veritable instrument for the succession of the incumbent king's first son, or failing which his next of kin succeed to the throne; and also provide a platform to address issues affecting the mutual concern of the king and those of the kingmaker in other for them to remain indefatigable in applying the law to sustain the position of the other. ${ }^{141}$ In spite of the royal decree, there are some exceptions recorded in history. It is on record that there were two kings that communicated a temporary change to their kingmaker in the choice of a successor among their children. These two kings were, Eweka 1 and the sons of Ohen.

Thus, the evolution of the primogeniture law as an instrument of royal succession in Benin brought considerable solidarity, peace and progress to the monarchical government of Edo land. From the foregoing, there are three major actors in the history of the development and preservation of the law of primogeniture -Arevbukhu in Benin Kingdom. The first was Ogiso Igodo who elevated the principle of the Urho system as an instrument of monarchical succession. The second was Ogiso Origba who consolidated the instrument through an all-time decree, and supplied all the provision for sustaining it. Finally, the untiring efforts of the Edionnisen (as the kingmakers were called during the Ogiso era) who became Uzama in the Oba era. This is why the kingmakers have been accorded the honour of first - class nobles in Benin. Without the primogeniture law the Benin monarchy would have lost its orderliness.

With the embrace of the primogeniture law within the Benin royal family, it application was extended to regulate the succession matter concerning every citizen of Benin. The implication was that with regard to the property of ordinary citizen; the eldest surviving male child is automatically transmogrified into his late father position after the final burial ceremony had been concluded. It is note worthy to mention here that with the exodus of persons from Benin Kingdom in the middle of the $15^{\text {th }}$ century during the reign of Oba Ewuare of Benin, who had two sons who tragically died on the same day, mourning the death of his sons Oba Ewuare declared to the whole kingdom that there shall be no sexual intercourse

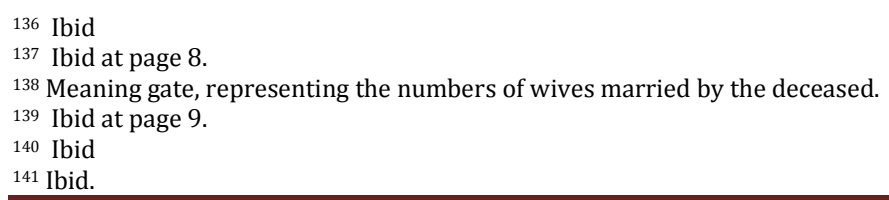

INTERNATIONAL JOURNAL OF INNOVATIVE RESEARCH \& DEVELOPMENT 
in the kingdom; no washing, sweeping of the houses or compound, drumming or dancing; and making of fire in the land. The Oba insisted that these laws must be strictly adhered to for a period of three years as a mark of respect for his dead sons ${ }^{142}$. However, those who could not endure this suffering ran away from Benin Kingdom to found other new settlements outside Benin kingdom. Historically, this is one of the accounts for the origin of the Esan people in the present-day Edo State. It is therefore not surprising that the rule of primogeniture that regulates succession and inheritance in Benin Kingdom is also applied amongst the Esan people on the same subject matter, however with some modifications.

\subsubsection{Types of Succession System in Benin Kingdom}

In Benin Kingdom, two major types of succession system are in place. These systems are generally described according to their form and characteristic, particularly as they provide for the orderly sequence in the succession system, which is known as the Asegbere. ${ }^{143}$ The second system is called the Ahannore. Under the Asegbere system of succession, there three sub classification. These are Azodionre, Azofure and the Arevbukhu. These succession systems are unique to certain category of persons. Thus, the Azodionre is use to select the head of the Okagbee ${ }^{144}$. While Azoture regulate the Odionwere ${ }^{145}$ selection and finally, the Arevbukhu regulate the Urho ${ }^{146}$ of the ordinary citizen. The Ahannore system basically controls the Avbure and the Azere/Azema succession pattern.

\subsubsection{The Azodionre System}

As it has been noted earlier, the Azodionre type of succession system in Benin Kingdom is that which is applicable to the Okaegbee. This system prescribes the age criterion as the basis of ordered succession to the title and property. The Okaegbee is the oldest male member of the (Okao) of a kingship (Egbee) and he over see the affairs of the nuclear families (Urho) clusters within it. It is on record that this age criterion principle of the Okaegbee system has from the earliest time been applied to village community. The village community is made up of a cluster of kingship families. It is important to state that at this level, the Odionwere or the oldest male member of the village community holds political authority. The application of the Odionwere rotational system has not been a successful venture beyond the government of the individual village community. It has thus continued to operate at the village level of the monarchical administration ${ }^{147}$

\subsubsection{The Azoture System}

The Azoture system of succession is one in which the Odionwere principle is applied to pee group called the (Otu) for the purpose of electing a leader. This system is distinguished able from Azodionre in the sense that while Azodionre is effective at the level of kinship families in applying the Okaegbee principle to choose a village leader known as the Odionwere who is the oldest man in the village for the purposes of village administration, while the Azoture system is effective at the level of village leaders or Odionweres by applying the Odionwere principle to choose a monarchical leader $\left(O g_{i e}{ }^{148}\right)$ who would exercise an over-riding authority over a wide range of village communities. It is similar to Azodionre in the sense that it is based on age criterion though this criterion is operated within the context of peer group. Also, it is generally believed that this system is also based on group criterion. It is on record that at the early stage of the history of Benin monarchy, the Azoture with its Odionwere principle was applied at the monarchical level during the period of the "Do-Nothing Ogiso" (1000-1050 AD), the period immediately following the Igodomigodo (900-1000 AD), during which 19 kings ascended the throne in quick succession.

\subsubsection{Arevbukhu System}

This system of succession belongs to the Asegbere classification it application applies directly to the nuclear family called the Urho. This system prescribed the birth criterion as the condition for the succession to the title and property of the deceased. The Urho system specifically ensures that it is the eldest son of man that should succeed to his position and property when he dies. The peculiarity of this system is that, unlike Azodionre and Azoture, which allow the rotation of the succession chances in ordered pattern, the Arevbukhu concentrate it on the same family line. It is only when that line fails by hairlessness that the next of kin is invited into the succession system, not only to ascend the throne, but also to continue the Arevbukhu practice in his crown family. ${ }^{149}$ It is a commonly held view amongst Ubiniologist ${ }^{150}$ that this system is the most successful among the various methods that has been experimented with in relation to the monarchical succession system in Benin Kingdom. The advantage of this system is that it eliminates all strife and

\footnotetext{
${ }^{142}$ See the History of Esan people available at http://www.discoveresan.com/history (last accessed on the 16th July 2018). Also, another account claimed that after Oba Ewuare became the king, he had two sons named Kuoboyuwa and Ezuwarha respectively. They both loved themselves dearly. While the older son Kuoboyuwa was the "Edaiken" [Edayin'Iken] of Uselu, the younger son was made the "Ogie" of Iyowa. As show of their affection, they usually exchange gifts between themselves until one day when the younger brother misjudge the senior brother gesture of sending him gift of farming implement in return of his own gift of yams. This he interpreted to mean that his brother was calling him a "bushman". This act, introduced hatred between them, which eventually resulted in their poisoning one another, as a result of which they both die the same day. For further reading, see J.0. Omokhodion The Sociology of the Esans (2012 Titus Obembe Press) at 8-9.

143 Ibid at page 7.

${ }^{144} \mathrm{He}$ is the head of the extended family consisting of several units that shear the same ancestry.

145 This is the oldest person in a village.

146 Refers to door I .e the number of women the deceased married.

147 Ibid.

${ }_{148}$ A Duke. The word is not used in the sense as it applies to the British. A duke under Benin Native Law and Customs is a male ruler of a collection of villages who report to the Oba of Benin.

149 Ibid.

150 Expert in the study of Bini traditional history and its Native Law and Customs.
} 
competition for the throne because it is known that the eldest son of the incumbent ruler is alive, or there is an identified next of kin in the line of succession to the throne. The same reasons can be adduced with respect to it application to individual families. Once the eldest son of a deceased person is identified, every body within the family unit knows that he is expected to step into his father's shoes as the head of the family after his death and by extension, there are certain things that he will be required to possess or acquired to be able to function properly in that capacity as the new head of the family. These things, or property are not part of the estate of the deceased to be shared amongst the other children of the deceased.

\subsubsection{Avbure System}

Avbure system belongs to the Ahannore classification. This system makes provision for an aspirant to a title and property to apply to a higher authority such as the Oba for consideration into the position. At the heart of this system, the applicant reserves the right to make his own selection among the non-hereditary titles that are vacant and he must be satisfied that whatever he is applying for is what appeals to him the most. This system demand that the applicant must be fully prepared to satisfy all the conditions required for the attainment of the desired position under native law and custom. For example, in Benin Kingdom, there are certain chieftaincies titles that are not hereditary and that are opened to well-meaning members of the society. The Avbure system of succession plays a significant role in the selection of the recipient to take any of these titles when the former holder dies.

\subsubsection{Azere or Azema System}

This is the second system under the Ahannore classification. Under this system, a ruler invites a subject to take over a chieftaincy title. The decision to pick a particular person for the position is at the discretion of the ruler after taking into consideration all positive facts and quality of the recipient, which are favourable to the ruler. This system is distinguishable from Avbure system in the sense that while the application comes from the recipient in Avbure system, under the Azere or Azema system, the direct opposite is the case. Thus, both classifications belong to the Ahannore system of succession because they are executed by random choice rather than by orderly and predetermined choice, which is normally associated with Asegebere system. ${ }^{151}$

\subsection{Law of Succession under Esan Customary Law}

The customary law that regulate succession in Esan land is somewhat difference from what is obtainable in Benin Kingdom in certain area. These two ethnic groups, the Edos and Esan, are among the key ethnic groups that constitute the present-day Edo State. Historically, the initial settlers / founder of Esan land was said to have migrated from Benin Kingdom. This explains the similarity in the customs and traditions between these two groups. In Esan land consist of 28 communities with their autonomous traditional ruler known as the Onojie152. It is worthy of note to mention that even amongst these 28 communities that constitute Esan land, there exist amongst them notable variations in the application of customary law rules regulating issues relating to succession and inheritance. In spite of these differences, there are seven basic laws governing the selection, succession and installation of an Onojie ${ }^{153}$ in Esan land. Although the rule of primogeniture is strictly adhered to, there are other rules that are applicable in conjunction with this rule. These rules are as follows: (a) the title of Onojie (traditional ruler) is hereditary, which passes from father to son. (b) The first surviving legitimate son success his father. (c) There can be no lawful succession until after the burial ceremonies of the late Onojie have been completed, in accordance with native law and custom. (d) He who performs these burial ceremonies inherits the family property, which is not shared, and succeeds to the title and throne absolutely. According to Dr Okojie, these burial ceremonies have the greatest significant under Esan customary law of inheritance, and hence this fourth law is of over riding importance. (e) Once an Onojie, always an Onojie. Once someone has been duly installed as an Onojie according to native law and custom, nothing but death removes him from the throne. (f) The title, been that of a constitutional monarch, which is held in trust for the community cannot be willed or voluntarily relinquished in favour of any son, brother, uncle or a trusted friend. (g) The official burial place of an Onojie is at a special spot or location in Eguare.154

These rules ensure that a uniform system of succession is maintained throughout Esan land. The important of these rules cannot be over emphasised. For example, the first rule ensures that a son succeeds to the property of his later father, and a single line of succession is maintained. The only exception is when the Onojie dies without an heir. In such a situation, the right to succession passes to the late Onojie's surviving most senior brother. If no brother, the right passes to his eldest uncle. ${ }^{155}$

The second rule satisfied the customary law dealing with the rule of primogeniture that provides that every first son inherits his late father's worldly possession. This rule is of uniform application across Esan land. With particular reference to the Onojie's stool, if an Onojie has several sons and the eldest of them dies, leaving male children of his behind to succeed him with regard to his own personal estate, such male children, the first amongst them cannot lay any claim to the throne after the death of the current Onojie regardless of the fact that his late father was the late Onojie's first son. The reason being that by the operation of customary law, since the first son predeceased his father, the right to succession automatically falls on the second son who now become the eldest surviving son of the late Onojie. The children of the

\footnotetext{
151 Ibid

152 These are the names of the 28 communities that constituted Esan Land. Irrua, Uromi, Ekpoma, Ubiaja, Ugboha, Ewohimi, Ewu, Igueben, Ohordua, Ebelle, Ugbegun, Opoji, Okhuesan, Ekpon, Ewossa, Emu, Amahor, Ogwa, Ugun, Oria, Ewatto, Urohi, Uzea, Udo, Ukhun, Egoro, Ujiogba and Idoa.

153 C.G. Okojie. Esan Native and Custom with Ethnographic Studies of the Esan People, (1 ${ }^{\text {st }}$ ed, Reprinted 1994 Ilupeju Press Ltd) at 67.

154 Ibid

155 Ibid
}

INTERNATIONAL JOURNAL OF INNOVATIVE RESEARCH \& DEVELOPMENT 
former dead son under customary law have no claim whatsoever to the title as long as their uncle is alive. It is important to emphasis that for a male child to benefit under the operation of the rule of primogeniture, such a son must be a legitimate child. Children from a lover / lovers, (Omon Osho) or from an Arebhoa ${ }^{156}$ does not have any claim to the title under customary law. ${ }^{157}$ The application of this rule restricting succession to the throne by foreclosing children from "Omon Osho" might appears discriminatory in nature, when juxtapose with the provisions of section 42 (2) of the Constitution of the Federal Republic of Nigeria 1999 (as amended). 158 The reason being that such a child, even though his father might have accepted his paternity, he is still being discriminated against because of the circumstance of his birth and he is considered as not being a fit and proper person to succeed to the throne because his mother was never married according to customary law. But the situation could be different if the Onojie does not have any child at all. However, the same cannot be said for a child given birth to by an Arebhoa for obvious reasons. Encouraging such a child, will amount to disruption in the line of succession.

The third rule ensures that the proper customary burial ceremonies are observed and performed. There is an idiom in Esan language that goes thus: "Ei se bhe Eguale abha mien ojie" meaning the throne is never vacant. Immediately after the death of an incumbent Onojie, the kingmakers will immediately install the heir and he must as a matter of urgency commence the burial ceremonies at once. The implication of failure to perform the burial ceremonies or not completing it after stating one is the lost of the throne by the linage of the heir. In such a situation, the next senior brother will be called upon to ascend the throne not withstanding that the dead heir has children who could have being installed as the next Onojie.

The fourth rule appears to be the most important having its uniform application to the crown and the ordinary persons. This rule stipulates thus: "Onon luogbe ole nab he ogbe" meaning (he who performs the burial ceremonies owns the house and all there-in) this customary law is based on the necessity to bury the dead Onojie and bring him in harmony with, and associate with the spirits of the departed Enijie ${ }^{159}$. It is believed that the spirit of the newly departed Onojie merely hangs about in the next world with no abode or respect until he has been buried according to native law and custom. ${ }^{160}$ Since succession right to the throne is conferred on the person who performs these burial rites, this in tune places a grave responsibility on shoulders of the kingmakers by not allowing or accepting any person other than the first surviving legitimate son of the departed Onojie to perform the burial ceremonies. Furthermore, this rule of customary law is also applicable to ordinary citizen within the community. It is the deceased first surviving son that performs the final burial rites of his late father before he is entitled to inherit his estate. However, where the son is a minor, it is permissible for an older uncle to perform these burial ceremonies for him (the nephew) the uncle then inherits the property which he holds in trust until the boy attain majority. However, where the heir to the throne as in the case of an Onojie, is a minor, the rules are completely different from the position enumerated above concerning the ordinary citizens. Where an heir is a minor the kingmakers will appoint an Akheoa (Regent) to administer the affairs of the chiefdom until the minor comes of age and performs the burial rites afterwards he is then installed as the Onojie. Under Esan native law and customs, the Regent must be the minor oldest uncle. He is not allowed under any circumstance to perform the burial ceremonies; and in any case, he cannot perform them on his dead brother because customarily he is forbidden from doing so. This is one of the methods introduced by the founding fathers of Esan land to ensure that the rule of primogeniture as it affects the throne is preserved.

The fifth law strongly support and entrench the existence of the Onojiship. The rule ensures that once a person has been installed as the Onojie after the performance of the second burial ceremonies, he cannot be removed as an Onojie. Only death can remove an Onojie from the throne. In the event that the Onojie become sick and unable to function, an Akheoa (Regent) will perform his duties. In most cases, the Onojie first son is usually appointed or the Onojie's immediate brother. However, Dr Okojie ${ }^{161}$ argued that the notion or opinion, which, states that an Akheoa can become a substantive Onojie, is something new among the Esan people, which cannot be supported by any traditional or historical records. It origin cannot be ascertain and it is an aberration to Esan Native Law and Custom. It does not represent the correct position of Esan customary law of succession to the throne. The correct position of the law is that an Akheoa can never be a substantive Onojie 162 .

The sixth rule ensure that the succession to the throne follows the age long tradition as provided by Native Law and Customs. Thus, an Onojie cannot by a testamentary instrument executed by him bequeath the throne to any other person apart from his first son, who is the customary heir to the throne. Where any of such testamentary bequeath is made, that disposition will be cleared void $a b$ initio. The reason being that, the title (the throne) is not his personal property. It belongs to the whole communities constituting the chiefdom and he does not posses the powers to single handedly alter the age long customary law in favour of any one else apart from the first son who is customarily recognised as the heir to the throne. Although there could arise a situation where the heir would refuse ascending to the throne for reasons best known to him. Whenever such a situation arises, the solution, have already been provided by customary law.

\footnotetext{
156 An Arebhoa was usually a man 's first daughter (his Ehale). She is encouraged not to be married to any man. When she attained puberty, she lives in her father's house where she is permitted to have sexual relationship with any man of her choice. All the children from this association are deemed to be the children of her father. The only reward for the husband is uninhibited companionship at the girl's father compound. Also, the man is not expected to pay any bride price on the girl. This practice is encouraged where a man does not have male children that will inherit his estate when he is dead. This procedure provides an alternative means of having male children.

157 Ibid at 69.

158 See Cap C23 Laws of the Federation of Nigeria, 2004.

159 The plural form of Onojie.

160 C.G.Okojie. Esan Native and Custom with Ethnographic Studies of the Esan People, (1 ${ }^{\text {st }}$ ed, Reprinted 1994 Ilupeju Press Ltd) at 70

161 Ibid.

162 Ibid at 72 .
}

INTERNATIONAL JOURNAL OF INNOVATIVE RESEARCH \& DEVELOPMENT

DOI No. : $10.24940 /$ ijird/2018/v7/i8/ 131085-317209-1-SM 
The implication of such an act of rejecting the throne is an automatic lose of the customary right to the throne and the attendant right to inherit any property of his late father the Onojie. Under customary law, the option of who then become the Onojie is left for the kingmakers to decide. Also, another situation could arise where the heir to the throne performs the burial ceremonies of his late father in other to be able to inherit his properties and yet, refuses to ascend to the throne. Whenever such a situation arises, the customary law provides that succession to the throne will be shifted to a named person, to be chosen by the kingmakers of that particular kingdom. The person so chosen by the kingmakers will only occupy the throne legitimately during his lifetime to serve the period the legitimate heir refuses to occupy the throne. However, when he dies, succession to the throne does not continue with his children or his lineage because of the operation of the rule of primogeniture and the need to preserve a single linage of succession to the throne. Any legitimate claim he might have, is automatically extinguish by his death. Succession to the throne automatically reverts to the linage of the heir that performed the final burial rites of his deceased father (the Onojie) but refuses to ascend to the throne. Thus, by performing the burial ceremonies, the heir has established an irrevocable claim to the throne not only for himself, but also for his own offspring. Therefore, after the death of the person that renounces the throne and the person so chosen to replace him by the kingmakers, his own children and not the children of the chosen person to replace him have the legitimate right to succeed to the throne. ${ }^{163}$

Finally, the seventh rule or law deal with the final resting place of an Onojie. The rule provides that no matter the place and location where an Onojie dies, he must be brought to Eguare (the place) and interred at the official place. This spot is reserved for the interment of the Onojie. Under customary law no other person or persons no matter how popular or highly placed he might be, he cannot be buried on these sacred grounds exclusively reserved for the burial of the departed Enijies.

\subsection{Matrilineal Inheritance}

This mode of inheritance is the direct opposite of patrilineal inheritance. Under this system, inheritance is through the mother's linage. There are some isolated cases where this system of inheritance operates in Nigeria. For example, in Nembe community in the present day Bayelsa State, children inherit from their mother's family. A man property in the community is inherited his sister's children.

\subsection{Beneficiaries of Customary Inheritance}

In considering the rights of beneficiaries under customary law, it is important to consider whether the deceased die testate or intestate. These classifications would assist in determining the nature and scope of what is to be inherited by the beneficiaries. Thus, in most instances, issues relating to intestate succession arise where there is no Will left behind by the deceased, and the devolution of his properties are left to be determine in accordance with his personal law. A beneficiary is defined as a person who derives advantage from something, especially a trust, will, or life insurance policy. 164 It could also be defined as a person who gain as a result of something or a person who receives money or property when somebody dies. These definitions appear to be somewhat devolved of legal conations. According to Black Law Dictionary ${ }^{165}$, a beneficiary is "a person for whose benefit property is held in trust, especially one designated to benefit from an appointment, disposition or assignment (as in a will, insurance policy etc.), or to receive something as a result of legal arrangement or instrument." This definition is apt, in that its define who a beneficiary is under the law. Arising from the definition above, the pertinent question to ask at this stage is, how does one qualify as a beneficiary under customary law in a situation where the deceased died intestate? According to available research data provided by the Institute of Advance Legal Studies of Nigeria shows that children are generally regarded as the beneficiaries of a deceased person who died intestate. In some communities, if the deceased person is a male, and has no male child or children to succeed him, the biological sibling of the deceased is usually substituted in place of his biological children ${ }^{166}$. This position can only be correct if the deceased person married under customary law while he was alive. But if the deceased contacted a Christian monogamous marriage under the Act and died leaving a spouse behind even though there are no issues of such marriage, the customary law will not apply, rather the provisions of the Administration of Estate Law shall apply depending on whether his state has enacted its law on intestate succession (non-customary) law to regulate succession matters. But if his state has not enacted its own law on Succession, then the common law rule in the case of Cole v Cole shall apply. The position under Islamic is quite different from that explained above. Here, female children and wives qualify as beneficiaries which specific percentage of the estate of the deceased allocated to them by the Holy Koran. In other to under stand the position of the law more clearly, it is proper to distinguish the gender of the deceased. If the deceased person is a woman, the common practice is that all her children in respective of sex succeed to her estate. This principle appears not to be of general application amongst all communities. In some communities, there is diversity in the application of this above stated principle. It is possible to find some form of uniformity in some aspect and disparity in other aspect with regard to the application of this rule. Therefore, even in some situation, where there is uniformity with regard to compliance with some aspect of the rule, it is not uncommon for one to find some degree of disparity in its application even within the same locality or ethnic group. For example, it is a commonly held view that children, have priority in the inheritance of their parents' properties; but in the same vein, there are disparity about what each child can specifically inherit. Research has shown that these disparities are mainly along cultural lines. For example, one finds a

163 Ibid at 75

164 Oxford Dictionary of English (ODE) Second Edition revised (C) Oxford University Press 2005.

165 Black's Law Dictionary $9^{\text {th }}$ Edition for iPhone/iPad / iPad touch. Version 2.1.2 (B13195)

166 The Validity of this customary law has been seriously questioned by the courts because it offends the provisions of section 42 (2) of the 1999 Constitution (as amended). 
situation where sons inherit to the exclusion of female children in some communities. This is very common among the communities of the South-West and South-South Geo-political zone in the country. Amongst the Edo and the Esan speaking people of Edo State for example among the sons, there is disparity in the nature of the property that can be inherited between them. It is the exclusive preserved of the eldest surviving son of the deceased to inherit the Igiogbe of his later father. The other male children are foreclosed from consideration by the customary law. In fact, this principle of customary law has been statutory recognised by the provisions of section 3 (1) of the Will Law of Bendel State, applicable in Edo State. Apart from its recognition by statute, the courts have also enforced this provision in a number of cases ${ }^{167}$. Furthermore, with regard to the rights of an adopted child under customary law, there exist disparity on the type of property such an adopted child or an illegitimate child under customary law can inherit within the same family. In the case of an illegitimate child ${ }^{168}$, the position is straightforward. Such a child has no right of succession because his paternity cannot be established and linked to the family of the deceased.

Furthermore, in most of the communities of the South-East inheritance by daughters are somewhat limited and predicated on the performance of some customary procedure / rites. ${ }^{169}$ But the position is different amongst the Edo / Esan speaking people of Edo State and the Yoruba speaking tribes of the South-West. Between these two ethnic groups, there are disparities, which are often drawn on the distinction between the personal property of the deceased and family property, and between moveable and immovable properties. Interestingly, the right of a spouse i.e. a wife in relation to her late husband property is worth considering at this stage of this discuss. The right of a wife to inherit from the estate of her late husband under customary law appears to be non-existence. According to Margaret C. Onokan

on the death intestate of a husband, dispute often arise as to whether his widow can inherit his property. Whether a widow can inherit the intestate of her husband will depend on the customary law of the locality... under Igbo customary marriage law she has no right to inherit her deceased husband's estate but she can be granted the use of his land if she remains in the family after his death. Such grant being subject to her good behaviour, it cannot vest the estate in her. ${ }^{170}$

In Nezianya Azika v Okagbue 171 the court held that a married woman had no right to succeed to the estate of her late husband under Onitsha customary law. Thus, it was immaterial that she had been in possession of the property without the prior consent of any member of her deceased husband's family. Moreover, her long possession of it without any interference by any member of his family did not constitute a bar to the family's right of ownership of the property 172 . This position as expressed by the court finds expression in The Manual of Customary Law ${ }^{173}$, which provides that "a widow has no right of ownership over any property of her deceased husband. It is immaterial whether she has surviving sons or not. The only property of her husband which she has right to keep after the husband's death are outright gifts made by the husband in his lifetime."

In fact, her late husband relatives see her as an object to be inherited. However, in certain circumstance, a distinction is drawn between whether she has children for her late husband or not; or whether she has sons for her husband or only daughters. The researcher from the Nigerian Institute of Advance Legal Studies discovered that in certain communities, the chances of the woman benefiting in some form of inheritance from her late husband's estate is predicated on whether she has male children as against female children. ${ }^{174}$ Apart from the gender of the children, there is also the issue of whether the woman remains unmarried or whether she decided to remarry. The researcher from the Institute also discovered that in a situation where the woman is allowed to inherit from the estate of her late husband, that right is restricted or limited to the matrimonial home. They also discovered that in such situation, her rights are only possessory and not proprietary in nature. Thus, she is only entitled to live in the home only for the duration of her lifetime. She has no right however to dispose of the property and the mere fact that she is married to the deceased does not bestow upon her the titled of a part owner. The position stated above with particular reference to Igbo customary law has been seriously altered by the Supreme Court decision in the case of Onyibor Anekwe and Anor v Mrs Maria Nweke ${ }^{175}$ The court came down heavily against discriminatory inheritance practises against women, i.e., the girl child and married women. The apex court reversed itself and departed from its earlier judgement in a plethora of cases ${ }^{176}$ and held that Igbo customary law practise that barred a daughter and a wife from inheriting the property of their deceased father or husband was unacceptable in a civilised society such as Nigeria and that such custom is repugnant to natural justice, equity and good conscience. One of the questions the court was called upon to resolve in the appeal was whether the custom of Awka

\footnotetext{
${ }^{167}$ See the following cases. Idehen v. Idehen [1991] 6 N.W.L.R. (Pt.198) at 382; Ogiamien v. Ogiamien [1967] NMLR 247; Lawal -Osula v. Lawal -Osula [1993] 2N.W.L.R. (Pt.274) 158 and Agidigbi v. Agidigbi [1992] N.W.L.R. (Pt. 221) 98

${ }_{168} \mathrm{~A}$ child can acquire an illegitimate status under customary law if the father or putative father refuses to acknowledge his paternity. For further reading see P.O.Itua "Legitimacy, Legitimation and Succession in Nigeria: An appraisal of Section 42 of the Constitution of the Federal Republic of Nigeria 1999 (as amended) on the Rights of Inheritance" (2012) Vol. 4(2) Journal of Law and Conflict Resolution available at http;//www. academicjournal.org /J LCR (last accessed on $7^{\text {th }}$ of August 2018).

169 This custom is what is referred to as Oli- Ekpe among the people of Nnewi. Where the deceased has no male child or heir and has daughter, the custom demand that he may keep one of his daughters of marriageable age in the house to have children for him. Where this is done, the daughter acquires the same right of inheritance as the male child.

${ }_{170}$ C. O Margaret Family law (2003 Spectrum law series) at 355

171 [1963] 1 All N.L.R .352

172 Ibid.

$173[1977]$ at 313

${ }^{174}$ E. Azinge. Restatement of Customary Law in Nigeria (1 ${ }^{\text {st }}$ ed, 2013, Nigerian Institute of Advance Legal Studies) at 130.

175 [2014] LPELR -22697 (SC)

${ }^{176}$ In Ojiogu v. Ojiogu [2009] 9 NWLR (Pt. 1198) 1. SC Onnoghen JSC affirmed the position of the Supreme Court when he stated as follows: "A custom is the way of life of a people. This particularly one must have been borne out of the people belief that a woman, particularly a married one, is a chattel to be owned. Be that is it may, it remains the custom of the people unless in an appropriate case it is properly and legally declared repugnant to natural justice, equity and good conscience. In the instant case, both parties recognize this particular custom and relied on it in an attempt to establish their respective contentions. There was no question of the custom being repugnant."
} 
people of Anambra State which denies a woman of her right to her deceased husband or father's property is repugnant to natural justice equity and good conscience. In answering the question in the affirmative the court through Ogunbiyi JSC held as follows:

...My noble Lords, the custom pleaded herein, and is a similar custom in some communities wherein a widow is reduced to a chattel and part of the husband estate, constitute, in my humble view, the height of man inhumanity to woman, his own mother, the mother of nations, the hand that rocks the cradle. The respondent is not responsible for having only female children. The craze for male children for which a woman could be denied her right to her deceased husband or father's property is repugnant to natural justice, equity and good conscience...177

Also, His Lordship Ngwuta JSC in his concurring judgement in the same case condemned the Awka custom and similar customs that disinherited a woman from inheriting her deceased husband or father property under customary law. Accordingly, he held at follows:

...The carze for male children for which a woman could be denied her right to her deceased husband or father's property is not justified by practical realities of today's world. Children, male or female are gifts from the creator for which parents should be grateful. The custom of Akwa people of Anambra State pleaded and relied upon by the appellant is barbaric and takes the Awka communities to the era of cave man. It is repugnant to natural justice, equity and good conscience and ought to be abolished...178

It is worth noting that the apex court did not only declared this Akwa custom repugnant to natural justice, equity and good conscience, it went further to declare the said custom as the "height of man inhumanity to woman," "uncivilized" and above all a "return to the cave man era", it also declared similar customs practised elsewhere within the country as repugnant to natural justice, equity and good conscience and went further to state that the court will not hesitate to decisively and punitively dealt with the perpetrations of such customs. Ogunbiyi JSC stated this view of the apex court as follows:

... I hasten to add at this point that the custom of Akwa people upon which the appellant has relied for their counter-claim will only tend to depict the absence of the realities of human civilization. It is punitive, uncivilized and only intended to protect the selfish perpetration of male dominance, which is aimed at suppressing the right of the women folk in the given society. One would expect that the days of such obvious differential discrimination are over. Any culture that disinherits a daughter from her father's estate or wife from her husband's property by reason of God's instituted gender differential should be punitively and decisively dealt with. The punishment should serve as a deterrent measure and ought to be meted out against the perpetrators of the culture and custom...179

In the light of the above, the Supreme Court has set a new parameter for the assessment of certain aspect of customary law that tends to disinherit female children from inheriting their deceased father's estate or a married woman from inheriting the property of her deceased husband. However, under Islamic law female children and married woman are not barred from inheriting from their late father's estate nor the widow from the property of her late husband. Thus widows who are married under Islamic law and female children can inherit either from their deceased father's estate or from the deceased husband's property as guaranteed by the Holy Koran. ${ }^{180}$ Therefore the erstwhile dilemma women faces in terms of inheritance under customary law which was aptly capture by Candide Johnson when he said that "in most cultural jurisdiction in Nigeria, particularly the Ibo, Yoruba, Edo and Urhobo, the wife or widow of a deceased does not come within the meaning of family member so as to enable her acquire the rights and privileges accruing to the children of the family. She is regarded as a non-legal person and so cannot hold any right to property or inherit from her husband and in some cases even her father."181 From the foregoing, it is clear that most of these issues discussed above can no longer escape being tag discriminatory customary practises. Thus, in recent times, our court has given landmark decisions that has positively imparted on the statute of inheritance by daughters and married women. ${ }^{182}$ In Obusez v. Obusez ${ }^{183}$ the court was called upon to decide whether customary law was the applicable law in a situation where the deceased married under the Marriage Act and died intestate. The brother of the deceased has argued and urge the court to accept his submission that since the deceased died intestate, his estate must be administer in accordance with customary law wherein he will be entitled to his late brother's estate, there by excluding his wife. The court in rejecting his augments held in favour of the wife by stating as follows per NIKI TOBI JSC that "By contracting the marriage under the marriage Act, the deceased intended the succession to his estate under the English law and not Customary law" Therefore, his real property was to be distributed in the same manner as personal property under the statute of distribution.

\subsection{Who are the Beneficiaries to the Estate of a Deceased Person under Esan Customary Law?}

This section shall examine the beneficiaries to the estate of a deceased person under Esan customary law. Unlike what is obtainable in other part of the country, particularly among the Yoruba ethnic group, where all the children of the deceased participate in the sharing of the estate of their father, among the Esan people, the eldest son of the deceased

\footnotetext{
177 See footnote 175 above at 34 .

178 See footnote 175 above at 77

179 See footnote 175 above at 88

180 See Holy Qur'an Cap 4 verse 14.

181 C.A. Candide-Johnson “Inheritance Law and Women's Property Rights-How Just?" Been a paper delivered at the 1 $1^{\text {st }}$ Murtala Muhammed Memorial Summit organised by the Murtala Muhammed Foundation at the ECOWAS Centre Abuja, Nigeria 14th-15 ${ }^{\text {th }}$ February 2005, p5. Also available at http://w.w.w.greatbrakriver.com In Suberu v. Sunmonu [1957] 2.F.S.C. 31 at 33 Jibowu, F.J. held that " it is a well settled rule of native law and custom of the Yoruba people that a wife could not inherit her husband's property since she herself is like a chattel, to be inherited by a relative of her husband." See also Shaibu v. Bakare [1983] F.S.C. 115, Oshilaja v. Oshilaja [1973]CCHCL 30/10/73 at 11., Akinnubi v. Akinnubi [1997] 2 NWLR 144.

${ }^{182}$ See Onyibor Anekwe and Anor v Mrs Maria Nweke [2014]LPELR -22697 (SC)

183 [2007] All FWLR (Pt.374) at 245
}

INTERNATIONAL JOURNAL OF INNOVATIVE RESEARCH \& DEVELOPMENT

DOI No. : 10.24940/ijird/2018/v7/i8/ 131085-317209-1-SM

Page 434 
inherit the estate absolutely after the performance of final burial rites. This position represents the purest form of the rule of primogeniture. On like what is obtainable in Benin, where the eldest son of the deceased inherits the Igiogbe absolutely, while the other properties are shared. In Esan land the reverse is the case. However, the properties of a Bini hereditary chief are also inherited absolutely by his eldest surviving son after the performance of the second burial ceremony. He inherits the paraphernalia of the chieftaincy title exclusively. Under Esan customary law, these categories of persons are the beneficiaries to the estate of a deceased Esan man's estate. The first group are his children, then followed by this relation i.e. the deceased immediate family members, and finally his wives. Before discussing these various beneficiaries, it is important to explain certain terms that will feature in this discussion. OMO OSHO: this mean a child from a mistress. AREBHOA: an Arebhoa is usually a man's first daughter (his Ehale). She was not married out to any man. Rather she remains in her father's compound and procreate with any man of her choice. The children from this sexual relationship are deemed to be the children of the lady's father. The supposedly husband has unrestricted access to the girl father's compound. The man pays no pride price on the girl. This custom ensures that a man that does not have a male child and an heir is able to have an heir from this practise. Although this custom appears to be widely practised among most of the 28 chiefdoms or districts that constituted Esan land, this practise is however forbidden at Ugboha. 184 Apart from the procedure described above, there is a modify version of the Arebhoa system. In the modified version, there is usually an agreement between the girl's father and the suppose husband that half of the bride price would be paid. Apart from the issue of the bride price, there is also an agreement to the effect that the woman shall cohabit with her husband in his house as opposed to living in her father's house. However, under this system, the issue of the marriage is shared between the husband and the girl's father in the following order. The first issue of the marriage belongs to the girl's father. If the marriage was blessed with many issues, a son and a daughter were returned to the father-in-law. When these children later grow up, get married and have children of their own, a reciprocal return is made to their mother's father i.e., their paternal grand father; in the following order e.g. from the original marriage a son (Oko) and a daughter (Otiti) were returned to the father-in-law. When Oko had issues of his own he would return a boy while Otiti would return a girl to their natural father. In most of the chiefdom in Esan land its application has considerably been diminished. In fact, this practise has gone into extinction.

- Adebhomon: An Adebhomon is a son of a childless man or woman brought ${ }^{185}$ and adopted to the knowledge of his or her Egbele (Kindred). On the death of the person such an adopted 'slave' could perform the burial ceremonies of the adopter and inherit the property according to Esan law and custom. ${ }^{186}$

- Ominjogbe: Ominjogbe or an Akheoa usually refer to a person who is the head (not by age) of a family genealogical tree under Esan native law and customs. This position is hereditary in nature so long the person entitled has performed the burial ceremonies of his father. In places like Uromi, there is an additional qualification; the person must also have performed the Ogbe ceremony. Ominjogbe means the "first son of the first sons" traced from the progenitor of the family. Once the head of the family dies, his first son performed the burial ceremonies and assumed the headship of the family. Consequently, his uncles, his brothers and sisters all come under his control and according to tradition, once a year they all paid homage to him as the keeper of the family ancestral shrine during the "lluobo Ukpe"187 ceremony. However, there is slight difference in the culture of the Ekpoma as it relates to Ominjogbe. In Ekpoma, the position is held according to age of the member of the family. In other words, it moves from one Odion ${ }^{188}$ to the next. However, Dr Okojie has insisted that the correct Esan custom recognised the Ominjogbe as the first son of the first, the pivot upon which the family or Uelen revolves. 189

- Ehale:(Forehead): In Esan custom, a man's Ehale is his first daughter, no matter whether she is the man first child or not. She is accorded a special position of respect by the fact that she is first female child of her father.

- Brothers: Under Esan native law and customs, two categories of brothers are identifiable. They are the paternal and maternal brothers. However, the maternal brothers assume a position of importance when it comes to the question of inheritance.

- Abiekhe: The concept of Abiekhe appears to be fading into disuse, and inmost chiefdom or district its practise is totally extinct because of the numerous social problems arising from it application, and largely because of its incompatibility with the provisions of the 1999 Constitution (as amended). Under this system, a very rich man will marry for his son once he is born. The wife (usually a baby too) will be married to this little boy, by his father. Naturally, the baby girl will mature before the boy and she start to have children who according to custom are regarded as the children of the son. When the boy comes of age, he then starts to have sexual relationship with his wife, who before now would have been given birth as a result of having sexual affairs with other men of her choice. The children that this woman has given birth to from other men will be regarded as the boy children, and

184 C.G.Okojie. Esan Native and Custom with Ethnographic Studies of the Esan People, (1 ${ }^{\text {st }}$ ed, Reprinted 1994 Ilupeju Press Ltd page) at115

185 "Bought" here implies when it was fashionable to buy a slave during the era of slave trade. Since the abolition of slave trade, this practise has since gone into extinction in Esan land. What is common nowadays days is a situation where a heirless man adopt either a paternal or maternal brother's son and recognize such a boy as his own child. Once the process is completed, the child is so recognized under customary law. When he dies, the adopted child performs the burial rites and inherits his property. However, the procedures for the adoption must follow the laid down customary law steps for it to be valid. Also, some times a heirless man might refuse to adopt anyone. When such a man dies, his immediate younger brother inherits his property and such inheritance is valid under customary law.

${ }^{186}$ C.G.Okojie. Esan Native and Custom with Ethnographic Studies of the Esan People, (1 ${ }^{\text {st }}$ ed, Reprinted 1994 Ilupeju Press Ltd) at 116

${ }_{187}$ An annual festival performed by members of various families that traces their origin from the same progenitor. During this ceremony, prayers are offered to the spirit of the departed ancestors.

188 Means the oldest person in a family.

189 Ibid at page 117.

INTERNATIONAL JOURNAL OF INNOVATIVE RESEARCH \& DEVELOPMENT

DOI No. : $10.24940 /$ ijird/2018/v7/i8/ 131085-317209-1-SM 
they assume position of seniority to his biological children from the same woman. Other children he would have through this same woman or any other women would be inferior in term of seniority from the Abiekhe. Abiekhe simply means, "born to wait." With modernisation / civilisation, this practise has virtual been abandon in most of the Esan communities. The problem with this system is that the farther of the children born before the resumption of sexual relation between the boy and his wife would contest the paternity of these children. In fact, the court will not hesitate declare the custom as being repugnant to natural justice and equity. Once the paternity of these children is acknowledged by their putative father, the children are his in the eye of the law, and the boy can not contest their paternity.

- Children From Sexual Surrogate: According to Dr Okojie, for want of better descriptive words to describe this class of relationship, He used and adopted the phrase "Children from Legal Harlots." 190 With due respect to Dr Okojie, I would rather prefer to refer to them as children from a legally accepted marriage, but who are product of sexual surrogate. This group refer to children that are products of legally approved adulterous relationship. A man who is unable to have canal knowledge of his wife or wives will called his Egebele (kindle) and sacrifice a goat at the ancestral shrine thereby given his wife or wives licence to have sexual relationship with any man of their choice in other to get pregnant. Once such children are born, they are regarded as the children of the husband. The only restriction this system places on the women is that they must not have sexual relation with any member of the man's family or Egebele. Under the provisions of the 1999 Constitution (as amended) the husband of these women stands the risk of losing these children once their biological father contests their paternity in court.

- Children From Woman To Woman Marriage: Esan tradition encourages this form of marriage between two women. This system is distinguishable, and must not be confused with same sex marriage. Under this system a childless but very rich woman who does not want her property to go into the hand of stranger, and desiring a very well befitting burial ceremonies will "marry" a young girl by paying her pride price and bring her to live with her. The married girl is then allowed to have sexual relationship with any man of her choice. All the children from this relationship are deem the children of the rich women and they will be entitled to inherit her properties when ever she dies, but they must perform her burial ceremony before they are entitled to inherit.

- ADOPTION: The concept of adoption is also well known among the people of Esan land. For the process to be customarily legal, the procedure must be done at the ancestral shrine and with the full knowledge of the adopter's Egebele (Kindred). The procedure is commenced by the adopter announcing that he wants to adopt either the son of his younger brother as his heir. The adopter then kills a goat at the ancestral shrine and the meat is shared among the Egebele. From that moment, the adopted child becomes his son. It is important to state here that if by any event, the adopter happens to have his owner biological son, the adopted son maintain his seniority over the biological son in the other of inheritance.

\subsubsection{Order of Inheritance}

Generally, Esan native law and custom provide that when a man dies, his children inherit his property and all his possession in the first instance. If the man dies without any children, then the right to inherit goes to his maternal brothers. If he does not have any maternal brothers, then his paternal brother will be considered for inheritance. Finally, where the dead man does not have any paternal brother, the right to inheritance passes to the Ominjogbe of the Uelen. ${ }^{191}$ With regard to property, the rule of primogeniture is fully observed. Here the first son inherits his father's property and share to any of his junior brothers and sisters at his pleasure. Some persons have questioned the rationale for this custom in a contemporary world. They argued that the custom is discriminatory in nature, and that it should be abandon. However, others are of the view that there is nothing discriminatory in this custom, which can be trace in some degree to the Benin kingdom. They argued that this custom has been largely responsible for smooth customary transition from the former head of the family who is now dead to the present head that is the surviving eldest son. It is noteworthy to mention that the custom has its own inbuilt mechanism to ensure that the rest children are provided for. Thus, even when the rule provides that the first son should inherit all his father's properties, in practise he is enjoin to share to all his brothers and sisters. The reason is simple, if he wants to live in peace and harmony with his brothers and sisters; he is bound to share with them. If his siblings are of the opinion that he might not share the property with them, they might refuse to assist him with the burial ceremonies. In such a situation, he has no choice than to single handily performed the burial ceremony without any assistance, which might to expensive for to bear alone.

Also, a situation could arise where the first son entitled to perform the final burial rites is a minor. In such circumstance the rule allows the maternal brother, ordinary brother or the Ominjogbe in that order that will be the inheritor of the estate of the deceased after performing the necessary final burial rights on behalf of the minor. But it is incumbent on him to take the minor as his ward and treat him exactly as he would treat his own child 192 until the son attain majority. When the minor attains majority, the estate is handed over to him and he continue to function as the head of the family. It is pertinent to mention that while the first son is still a minor, there are limitations in the traditional roles he can play. For example, he cannot give out the hand of his elder sister(s) out in marriage under customary law. Such roles would be normally be performed by someone else. In most situations that role is usually perform by the minor's customary next of kin in the order stated above. He alone has the right to marry out the minor's sisters. Also, the next of

\footnotetext{
190 Ibid at page 118

191 Means the first born (son) among the first born (sons) of members of the same family who traces their origin to the same person on the family genealogical tree under Esan native law and customs

192 Ibid at 120
}

INTERNATIONAL JOURNAL OF INNOVATIVE RESEARCH \& DEVELOPMENT

DOI No. : 10.24940/ijird/2018/v7/i8/ 131085-317209-1-SM 
kin has the responsibly to marry for the minor when he comes of age. Once again when the minor comes of age, his rightful properties are returned to him and he continues from thereafter.

\subsubsection{Inheritance of Wives}

Apart from the general rule, there are other rules applicable under Esan native law and custom that regulate "inheritance" of wives after the death of their husband. The general rule is that the first son inherits all the wives of his late father with the exception of his own mother who is normally inherited by the son's uncle or the Ominjiogbe of the Uelen. ${ }^{193}$ Some time when there are persons i.e., amongst the children and uncles interested in inheriting these women, the right to inherit moves to any old man in the Uelen. ${ }^{194}$ It is important to mention here that the right to inherit a widow under Esan native law and customs does not apply to a princess (the daughter of an Onojie) when her husband dies and she becomes a widow. In such situation, the rule is that the princess is "remarried" again before her father. Although the princess is remarried for the second time, no bride price is paid for the "second" marriage. This is the only situation where a widow is remarried again in all the 28 (twenty-eight) chiefdom that constituted Esan land.

Also, if a man inherits the wife of a brother or of an Ominjiogbe or the wife of any member of that kindred, when he dies, such an inherited woman is not inheritable by the dead man's heir. In such a situation, the right to inherit passes to the dead man's senior brother. In all situation of widow inheritance, Esan native law and customs gives the widow the option to chose whether she consented to being inherited by her late husband's first son or any other member of his family, in a situation where the first son is the widow's child, she has the right either to agreed or to refuse to being remarried by her late husband's brother because she cannot marry her own son. Also, she has the right to determine whether she want to remain unmarried to any member of her late husband's family or whether she chooses to exercises her right to remain unmarried and remain in her late husband's house to take care of her children until her death, and finally, she has the option of returning to her family after the death of her husband to live for the rest of her life. Thus, it is not automatic that once a man dies, his wife or wives are immediately subjected to being inherited under Esan native law and customs.

\subsubsection{Inheritance by Daughters}

With respect to daughters, the rule governing their right to inheritance is straightforward. A woman does not posses the customary right to inherit in her late father's estate. That is why in Esan language there are two idiomatic expressions depicting this age long custom. They are as follows: "Okhuo ile Aghada bhe Uku" meaning a woman never inherit the sword and "El bie Omokhuo he ole Iriogbe" meaning no one give birth to a girl and named her the family keeper. ${ }^{195}$ According to Esan native law and customs, her rights reside in her husband house. But to every general rule, here are exceptions. To the general rule stated above, an exception exists. In the chiefdoms where the system of Arebhoa is practised, a woman assumes the role of a man for her heirless father and performed the burial ceremonies according to Esan native law and customs and accordingly inherits her late father's estate. This situation must not be confused with the privileges the Ehale nonodion (the first daughter) enjoys during her father's lifetime. All those privileges cease once the father is dead. Dr Okojie has provided the philosophy behind this reasoning by the foundering fathers of Esan land ${ }^{196 .}$ According to him "it was this attempt to keep property in the family that led to the custom that a woman, however wealthy, she may be is not allowed to bury her father. The reason behind this principle of customary law is that since "he who performed the burial ceremonies inherits the property," it will be inequitable to denial the woman the right to inherit after performing the final burial ceremonies. Thus, a man can decide to share his properties amongst his children, both male and female in his lifetime before his dead, and what ever is share to the daughter(s) they keep even after the death of their father. The man must be mindful not to give the Ijogbe to another child because customarily it belongs to his first son. In the past, where a man dies without an heir, but he is survived by a daughter or daughters, the next male in line of succession steps in to perform the burial ceremonies. The daughters are prevented from performing the burial ceremonies. At the end of the ceremonies, the male member inherits the late man's property to the detriment of his daughters. This custom has been challenged in court and the court has held that the custom is discriminatory against female children and also it is in conflict with the provisions of the Nigerian Constitution ${ }^{197}$ Since daughter are not entitled to inherit any property after their father's death, the responsibilities of taken adequate care of those that are not yet married, rest squarely on the shoulder of the first son. He also has the responsibility and customary right to married them out and collects their respective bride price as the head of the family. It is important to mention that a man can give any of his property to his daughter(s) before his death save for the ancestral home. When such gifts are made, they remain valid even after the death of the man. Although the customary law expressly encourages the rule of primogeniture, the modern trend arising from judicial activism is that certain customary law principles that tend to discriminate against a girl child from inheriting from his late father's estate will no longer be encourage. Once a man dies without an heir, the court will not hesitate in allowing the daughter(s) to inherit their father's estate at the expense of their material uncles. Thus, the courts have always ruled that the children of the deceased no matter their sex are entitled to inherit in their late father's estate.

\footnotetext{
${ }^{193}$ See footnote 181 above.

${ }^{194}$ Means family.

195 Ibid at 124 .

196 Ibid.

197 See Salami v. Salami [1957] WRNLR 10; Adeseye v. Taiwo 1 FSC 84; Taiwo v. Taiwo 3 FSC 80; Lopez v. Lopez 5 NCR 43 . See also the provision of Sec. 42(1) of the Constitution of the Federal Republic of Nigeria 1999 (as amended). Cap.C23 Laws of the Federation of Nigeria 2004

INTERNATIONAL JOURNAL OF INNOVATIVE RESEARCH \& DEVELOPMENT $\quad$ DOI No. : 10.24940/ijird/2018/v7/i8/ 131085-317209-1-SM 


\subsubsection{Domestic Animals}

Usually, under Esan native law and custom, domestic animals like cows, goats, sheep, fowls belong to the children. Here the first son has absolute rights over these domestic animals. However, in the interest of peace, the first son ensure that he share some to his other brothers where the livestock is large. The sharing is usually done according to the numbers of wives the deceased had when he was a life. The sharing is amongst the first son from each woman represents each door. This practise is to ensure that at least a child from each wife is taken into consideration. The formula is applicable where there is more than one wife. If the first heir is a minor, then his uncle will inherit the livestock and take care of them till the heir comes of age.

\subsubsection{Debts}

Assets and liabilities are inheritable under Esan native law and custom. ${ }^{198}$ Thus a man's unpaid debt passes squarely unto his heir. The custom expects the heir to inherit both assets and liabilities of his dead father. The other children are not under any obligation to assist the heir with the payment of the debts. In fact, their intervention is done at their own pleasure. The only way the heir can escape the payment of the debts is to renounce his claim to all inheritance of his father's estate. In such situation the Egbonughale age group then takes the responsibility for the burial of the dead man. Since technically the deceased died without an heir, his properties, both assets and liabilities are inherited by the Onojie (the traditional ruler) that has jurisdiction over his community.

\section{Grounds for Disinhering an Heir under Esan Customary Law}

There are various grounds that can disqualify an heir from inheriting his late father's estate under Esan customary law. Since the rule of primogeniture is fully operational amongst the Esan tribe, the nature of the offence committed by the heir to justify his exclusion from inheritance must be very grievous in nature. The consequence of such exclusion is the denial of his position as the legitimate heir. Below are the grounds for disinterring an heir under Esan native law and customs.

\subsection{Disinheritance by the Father}

Under Esan Native Law and Custom, a man could dis-inherit any of his children. Usually this practise is really applied. However, the man in a moment of anger as a result of sheer wickedness and repeated damage by the heir to his property, integrity and bring the family's name to disrepute can dis-inherit his first son, by following these laid down customary procedures. Firstly, he will slaughter a goat at the ancestral shrine with the announcement that from that day onward, the heir ceases to be his child for all purposes. He is duty bound to inform all members of his family / extended families (Egebele). If the situation is not reverse before the death of the father, the heir losses his seniority in that family and the next male child in line according to seniority automatically become the heir who shall customary perform the final burial rite after the death of their father. ${ }^{199}$ However, if the man wishes to revoke the announcement, he is also required by custom to slaughter another goat before the ancestral shrine in the present of his kinsmen. Once this step is taken, the child becomes reintegrated into the family and his position restored.

However, In the case of an heir to the throne of an Onojie, (the traditional ruler) the rules are a bit different. Here two properties are involved, i.e., the personal private property of the late Onojie and the property that belongs to the stool. An Onojie can dis-inherit his heir when it comes to his private property but he cannot deprive him from ascending the throne as the Onojie (king). The reason being that the stool belongs to the community in generally and the Onojie is seen as the custodian of the stool and also of the native law and customs of the people.

\subsection{Debts}

It's trite principle of Esan customary law that an heir inherits the assets and liabilities of his father after his death. Where an heir finds it difficult to of settle the debts owe by his late father, thereby making it impossible to bury the deceased, the age group known as Egbonughele will then take over the responsibility for the burial ceremonies. In such a situation, the heir is relieved of the responsibilities of organising a befitting burial ceremony for his late father. Once this is done, the heir is automatically disqualified from inheriting his late father's estate. The debts are considered bad debts, and the Onojie inherits the property of the deceased. However, in contemporary times, the practise is to get any member of the family who will be willing to assist in the payment of the debts, or alternatively the property is sold to offset the debts thereby taken a way the object for inheritance.

\subsection{Adultery with the Onojie's Wife}

Adultery, which is known as "Ugboghele"200 among the Esan tribe can be committed in different manner. Strictly speaking, adultery was limited to a man having sexual relationship with the wife of another man of the same Egbele i.e. members of the same patrilineal or people who descend from one father. ${ }^{201}$ On like what is considered as adultery today, it was not possible to commit adultery with a woman from a different village or clan. If a person from a different village tries to seduce another man's wife in the market place or any other place, the woman's husband will waylay the seducer and attack him. But where they are from the same village, the woman's husband will report the matter before the elder who after listening to the allegation will fine the guilty person and the necessary traditional sacrifice will be performed at the

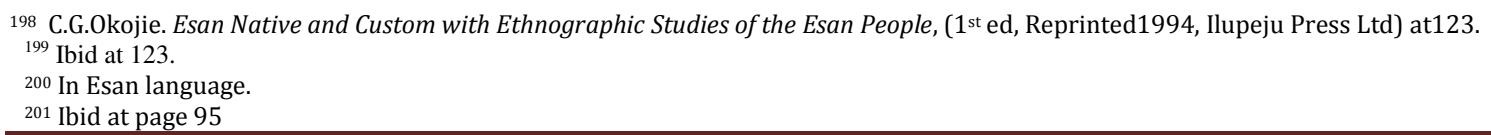


ancestral shrine of the Egbele. While the woman has to undergo some purification, rites performed by an Omonkuian (a married daughter of the Egbele).

When adultery is committed against the Onojie's (king) wife, amongst the Esan people the gravity of this crime is viewed with the same degree as to murder under Esan native law and customs, the punishment as prescribe by the native law and customs is death for the man and woman. Thus, if the man is an heir in a family with the pronouncement of the death sentence on him and the eventual execution, he is no longer in a position to inherit any property. Thus, he is automatically deprived from any form of inheritance of his father's estate. However, Esan native law and customs also empower the Onojie to exercise his discretion either mitigate their punishment or not before given final judgement on the matter. The Onojie could substitute banishment from the chiefdom for death. In either case, the heir still losses his right to inheritance because once banished, he can no longer come to back to that chiefdom again in his lifetime.

With the advancement of Christianity and civilisation, statutory law is now regulating these traditional sanctions for these offences. Thus, the Onojie can no longer sentence anyone to death or banish such a person who commits adultery with any of his wife.

\subsection{Banishment (Anolen Ubi Kua)}

According to Dr Okojie for the punishment of banishment to be pronounced, the crime must be grave, and second only to crime for which the punishment is death. These include persistent practise of witchcraft, having hand in causation of diseases, possession of bad medicine's etc. Any person who has been adjudged to be guilty of these offences is usually banish from the community. If the person happens to be an heir, once he is escorted outside the village by the Egbonughele and the Igene age group, he can no longer return to the village again. Consequently, he automatically losses his rights to inherit the estate of his late father.

\subsection{Murder}

Among the Esan, murder like adultery has a limited meaning. It is not all killing that constitute murder. For example, if a man goes into another village where they do not have the same "okoven" or boundary and kill some one from that village his action will not be seen as murder. Similarly, when death results in the course of a wrestling contest, such death was not seen as murder. Thus, in the past, the Esan people see murder as the killing of a person from the same village or a person from a village under the same Okoven. Thus, if the murderer is an heir, he is sentence to death by the elder council of the village. In such a situation the heir losses his right to inherit his father's estate. The situation is the same where the heir deliberately kills his own father in a bit to facilitate the inheritance of his father's estate. In such a situation, it will be difficult for such an heir to perform the burial ceremonies that will entitled him to inherit his father's estate. Such an heir will discover that his effort was a total waste of time. Nowadays, this customary law is no longer effective because the provisions of Criminal Code are now regulating the definition of murder. Thus, jurisdiction over this particular offence has since been taken from the ambit of the traditional instruction.

\section{Conclusion}

This paper has been able to discuss the various conditions that could ultimately lead to the disqualification of an heir inheriting his father's estate. It important to state here that the likelihood of an heir being dis-inherited is not common. The offence must have to be grave to attract such punishment. Also, because of the rule of primogeniture it becomes impossible for such disqualification except in the circumstance discussed above. However, where such disqualification exists, the custom equally provides the process for getting a replacement in other not to allow a vacuum to exist which will have a negative impact of the custom of the people. However, it pertinent to point out most of the customs discussed above particularly those relating to adultery, banishment, murder that were once under the absolute control of the traditional ruler (Onojie) has been taken over by the institution of the state. Must of this case will be referred to the officers of the Nigerian Police Force. When these cases are investigated, the offender will be made to face the sanctions as provided by the law. It is highly doubtful if such punishments as provided by the extant law will ultimately result in disinheritance except in a situation where the heir kills his father in other to facilitate / fast track the process leading to his inheriting his late father estate. Under Esan customary law, such a child will be forbidden by the family (Egebele) from performing the final burial ceremonies, there by foreclosing him permanently from laying any claim to his late father's estate.

\section{References}

i. Emola. Emiola's Africa Customary Law (3rd ed, 2011, Emiola Publisher Limited) at 77.

ii. A.A. Kolajo. Customary Law in Nigeria through Cases (Revised ed, 2001 Spectrum books Limited) at 156.

iii. A.G. Bryan Black's Law Dictionary (9th ed, for iPhone /iPad/ iPod touch version 2.1.2 B13195) at 1569.

iv. A.O. Abdulmumin. Religious and Customary law in Nigeria 25 Emory International Law.

v. Adegun v Fagbola [1932] 11NLR. 110.

vi. Adeleke v Iyanda [2001] 13 NWLR (Pt.729) 1.

vii. Adeniyi Oluwu \& Ors v. Olabowale Olowu \& Ors [1985] 3NWLR (Pt. 13) 372

viii. Adesoye v Taiwo 1 FSC 84.

ix. Administration of Estate Law Cap.1 Law of Western Nigeria 1959.

X. Administrator -General v Egbuna \& Ors, 18 NLR 1

xi. Administrator General v Tunwase \& Ors. [1946] 18 NLR 8

xii. $\quad$ Agidigbi v Agidigbi [1992] NWLR (Pt.221) 98 
xiii. $\quad$ Akinnubi v Akinnubi [1997] 2 NWLR 144

xiv. Akinnubi v Akinnubi [1997] 4 NWLR (Pt.486) 144.

xv. $\quad$ Amadi v Nwosu [1992] 5 NWLR (Pt.78) 40.

xvi. $\quad$ Amuda Adebambo \& 2 Ors v Daudo Olosago \& 3 Ors [1985] 3 NWLR (Pt. 11) 207.

xvii. Anyabunsi v Emmanuel Ugunze [1995] 6 NWLR (Pt. 401) 255

xviii. Ayisatu Tapa \& Ors v Yanrata Kuka [1945] 18 NLR 5

xix. Black's Law Dictionary 9th Edition for iPhone / iPad / iPad touch (2009-2013).

xx. Ewokor. Nigerians go crazy for life 1 August 2007 BBC News Retrieved 3September 2010.

xxi. C.A. Candide -Johnson. "Inheritance Law and Woman's Property Right - How Just?" Being a Paper delivered at the $1^{\text {st }}$ Murtala Muhammed Memorial Summit organised by the Murtala Muhammed Foundation. Available online at http://www.greatbrakriver.com

xxii. C.G. Okojie. Esan Native Laws and Customs with Ethnographic Studies of the Esan People (1 $1^{\text {st }}$ ed, Reprinted 1994, Ilupeju Press Ltd) at 125.

xxiii. C.O. Margaret. Family law (2003 Spectrum Law Series) at 352.

xxiv. Cole v Cole [1898[1NLR 15.

xxv. Constitution of the Federal Republic of Nigeria 1999 (As Amended) Cap. C 23 Laws of the Federation of Nigeria 2004.

xxvi. D.H. Parry. The Law of Succession: Testate and intestate (1972 Sweet and Maxwell Ltd London) at 1

xxvii. Daily Champion (Lagos) "Nigeria Wife Bashing - Deji of Akure Deposed, Banished" available on line at http://www.alafrica.com

xxviii. E. Azinge. Restatement of Customary Law in Nigeria (1 $1^{\text {st }}$ ed, 2013, Nigeria Institute of Advance Legal Studies Lagos) at 78.

xxix. E.I. Nwogugu. Family Law in Nigeria (2011 HEBN Publications Ibadan) at 372

xxx. Folani v Coke [1986] 2 NWLR (Pt. 22) 367.

xxxi. Frank Coker v George Coker \& Ors [1938] 14 NLR 83.

xxxii. Gbamgbose v Osabu [1988] 2NWLR (Pt. 78) 509.

xxxiii. History of Esan People available online at http://www.discoveresan.com

xxxiv. I.E. Sagay. "Customary Law and the Freedom of Testamentary Power" (1995) Vol.39 (2) Journal of Africa Law Cambridge University Press available online at http://www.Justor.org

xxxv. I.E. Sagay. Nigeria Law of Succession Principles, Cases, Statutes and Commentaries (1st ed, 2016, Malthouse Press Limited) at1.

xxxvi. I.Shahar. Legal Pluralism and the Study of Sharia Court (2008 5 Islamic L\& y') at 12.

xxxvii. Idehen v Idehen [1991] 6 NWLR (Pt. 198) 382.

xxxviii. J.K. Thornton. Warfare in Atlantic Africa 1500- 1800 (1999 London and New York Rutledge) cited in E. Azinge (ed) Restatement of Customary law in Nigeria (1st ed, 2013, Nigeria Institute of Advance Legal Studies Lagos) at 3.

xxxix. K. Akua "Women, Marriages and intestate Succession in the Context of Legal Pluralism in Africa" being a paper delivered at the 23 Brigitte M. Bodenheim Lecture on Family Law at UC Davis School of Law in January 2006.

xl. $\quad$ Lawal -Osula v Lawal-Osula [1993] 2NWLR (Pt.274) 158

xli. Lewis v Bankole [1908] 1NLR 81.

xlii. Lopez v Lopez 5 NCR 43.

xliii. M. Okunola. "Relationship between Islamic Law and Customary Law of Succession in Southern Nigeria" in B. Ajibola (ed) Towards the Restatement of Nigerian Customary Law (1991) Federal Ministry of Justice Lagos) at 185.

xliv. M.A. Okunlola. Interaction between Islamic Law and Customary Law of Succession among the Yoruba People. Unpublished $\mathrm{PhD}$ thesis (1985) at 255.

xlv. Marriage Act Cap. M6 Law of the Federation of Nigeria, 2004.

xlvi. Marriage Act Cap.115 Law of the Federation of Nigeria, 1958.

xlvii. $\quad$ Mojeku VMojeku [1997] 7 NWLR 238

xlviii. Mrs Lois Chituru Ukeje \& Anor v Mrs Gladys Ada Ukeje [20014] 1LPELR 22724 (SC).

xlix. $\quad$ Ndukwe v Acha [1998] 6 NWLR (Pt. 552) 25.

l. Nezianya Azika v Okagbue [1963] 1 All NLR 352

li. Nezianya v Okagbue [1963]1All NLR 12.

lii. O.S.B. Omoregie. "How The Primogeniture Law became Royal in Benin" (2003) Vol. 1(4) ISPU News Letter page 7.

liii. Obusez v Obusez [2001] 5 NWLR (Pt. 736) 377.

liv. Ogiamen v Ogiamen [1967] 1 All NLR 191.

lv. Ojiogu v Ojiogu [2009] 9 NWLR (Pt. 1198] 1 SC

lvi. $\quad$ Oke \& Ors v Oke \& Ors [1974] All NLR 401.

lvii. Olowosago v Adebanjo [1988] NWLR (Pt.88) 275.

lviii. Onowhosa v Odiazou [1999] 2 NWLR (Pt. 586) 482.

lix. Onyibor Anekwe \& Ors v Mrs Maria Nweke [2004] LPELR-22697 (SC)

lx. Oshilaja v Oshilaja [1973] CCHCL 30/10/73 p11

lxi. Oswagwu v Soldier [1959] NRNLR 39

lxii. Oxford Dictionary of English (ODE) Second Edition revised (2005 Oxford University Press) iPhone version. 
lxiii. P.0. Itua "Succession Under Customary Law in Nigeria: Igiogbe Matters Arising" (2011) Vol. 3(7) Journal of Law and Conflict Resolution page 117-129 available online at http://www.academicjournal.org

lxiv. P.O. Itua. "Legitimacy, Legitimation and Succession in Nigeria: An appraisal of Section 42 of the Constitution of the Federal Republic of Nigeria 1999 (as amended) on the Right of Inheritance' (2012) Vol. 4(3) Journal of Law and Conflict Resolution pages 31-44 cited in E. Azinge and A. Awah (ed) Legal Pluralism in Africa: A Compendium on Africa Customary Law (2012, Nigeria Institute of Advance Legal Studies Lagos) at 589.

lxv. P.O. Itua. "Succession Under Customary Law in Nigeria: Igiogbe Matters Arising" (2011) Vol. 3(7) Journal of Law and Conflict Resolution page 119 cited in E. Azinge (ed) Restatement of Customary law in Nigeria (1 ${ }^{\text {st }}$ ed, 2013, Nigeria Institute of Advance Legal Studies Lagos) at 78.

lxvi. R.A.I. Ogobobine Materials and Cases on Benin Land Law (1978 Bendel Newspaper Corporation, Benin City) at 36.

lxvii. R.J. Smith. Property Law (5 ${ }^{\text {th }}$ ed, 2006, Pearson Longman) at 3.

lxviii. S.NC. Obi. The Ibo Property Law ( 1962 Butterworts Africa Law Series) No 5 at 30.

lxix. Salami v. Salami [1957] WRNLR 10

lxx. Sanusi v Makinde [1994] 5 NWLR (Pt.343) 214.

lxxi. Shaibu v Bakare [1983] FSC 43

lxxii. Suberu v Summou [1957] 2 FSC 31

lxxiii. Succession Edict 1987.

lxxiv. T.O. Elias Nigerian Land Law and Custom(1962) at 234.

lxxv. T.O.Ocheja. "Dualism in the Law of Succession in Nigeria" in E Azinge and A. Awah (ed) Legal Pluralism in Africa: A compendium of Africa Customary Law (2012 Nigeria Institute of Advance Legal Studies) at 586.

lxxvi. Taiwo v Taiwo 3 FSC 80

lxxvii. Taylor v Williams [1935] 11 NLR 110.

lxxviii. The Holy Qur'an.

lxxix. The Manual of Customary Law [1977] at 33.

lxxx. The Pilot. "Tension in Edo over deposition of Uromi Monarch" available at http://www.nigerianpilot.com

lxxxi. Thomas v De Souza [1929] 9 NLR 81.

lxxxii. Traditional Rulers and Chief Edict No 16 of 1979 Law of Bendel State applicable to Edo State.

lxxxiii. V.C. Ikpeze. Gender Dynamics of Inheritance Rights in Nigeria. Need for woman Empowerment (2009 Folmech Printing \& Publishing Co, Ltd) at 113.

lxxxiv. Wills Act, 1837.

lxxxv. Wills Amendment Act 1882.

lxxxvi. Wills Law Cap.133 Laws of Western Region of Nigeria 1959.

lxxxvii. Wills Law of Bendel State Cap. 172 Laws of Bendel State applicable to Edo State.

lxxxviii. World web 32 Dictionary thesaurus / dictionary.

lxxxix. Y.Y. Banbale. Acquisition and Transfer of Property in Islamic Law (2007 Malthouse Press Limited) at 11.

xc. Yinusa v Adebusokan [1968] NNLR 97.

xci. Zaidan v Zaidan [1974] 4UILR 283. 